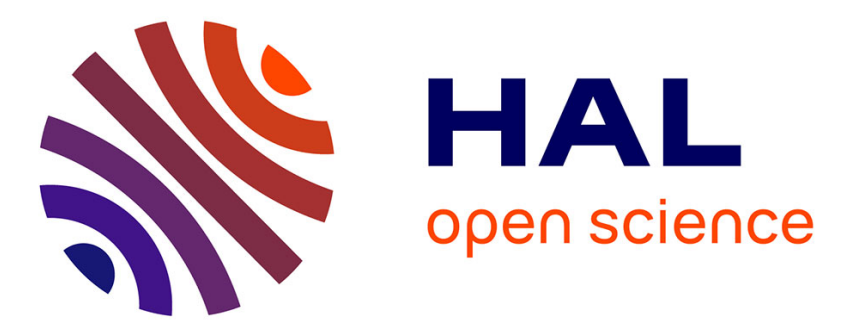

\title{
Water Vapour Effect on the Oxidation Mechanism of a Cobalt-Based Alloy at High Temperatures $\left(800-1,100{ }^{\circ} \mathrm{C}\right)$
}

Henri Buscail, R. Rolland, C. Issartel, S. Perrier, F. Riffard

\section{To cite this version:}

Henri Buscail, R. Rolland, C. Issartel, S. Perrier, F. Riffard. Water Vapour Effect on the Oxidation Mechanism of a Cobalt-Based Alloy at High Temperatures $\left(800-1,100{ }^{\circ} \mathrm{C}\right)$. Oxidation of Metals, 2014, 82 (5-6), pp.415-436. 10.1007/s11085-014-9500-9 . hal-01628634

\section{HAL Id: hal-01628634 \\ https://hal.uca.fr/hal-01628634}

Submitted on 3 Nov 2017

HAL is a multi-disciplinary open access archive for the deposit and dissemination of scientific research documents, whether they are published or not. The documents may come from teaching and research institutions in France or abroad, or from public or private research centers.
L'archive ouverte pluridisciplinaire HAL, est destinée au dépôt et à la diffusion de documents scientifiques de niveau recherche, publiés ou non, émanant des établissements d'enseignement et de recherche français ou étrangers, des laboratoires publics ou privés. 


\section{Water Vapour Effect on the Oxidation Mechanism of a Cobalt-Based Alloy at High Temperatures $\left(800-1,100{ }^{\circ} \mathrm{C}\right)$}

\section{H. Buscail 1,*}

Email buscail@iut.u-clermont1.fr

Email henri.buscail@udamail.fr
R. Rolland 1
C. Issartel 1

S. Perrier

F. Riffard 1

1 LVEEM, Laboratoire Vellave sur l'Elaboration et l'Etude des Matériaux, Clermont Université, UdA, Rue Lashermes, BP 70219, 43006 Le Puy-en-Velay, France

\section{Abstract}

A cobalt-based Phynox alloy has been oxidized in the $800-1,100{ }^{\circ} \mathrm{C}$ temperature range. The alloy oxidation is consistent with a growth mechanism limited by the diffusion process in a growing $\mathrm{Cr}_{2} \mathrm{O}_{3}$ oxide scale. Water vapour enhances the alloy oxidation rate and scale porosity. Thermal cycling tests at 900 and $1,000{ }^{\circ} \mathrm{C}$ show that water vapour reduces the outer $\mathrm{Mn}_{1.5} \mathrm{Cr}_{1.5} \mathrm{O}_{4}$ subscale adherence, but the chromia scale adherence is not affected. These temperatures permit a rapid chromium supply from the substrate to form a continuous chromia scale. At $1,100{ }^{\circ} \mathrm{C}$ thermal cycling conditions lead to the scale spallation and chromium depletion in the alloy. In dry air, weight losses are registered due to cobalt and molybdenum oxidation, giving $\mathrm{CoCr}_{2} \mathrm{O}_{4}$ and $\mathrm{CoMoO}_{4}$. In wet air, the initial porous chromia scale permits nickel and cobalt oxidation, leading to $\mathrm{Ni}_{5} \mathrm{Co}_{3} \mathrm{O}_{8}$ and $\mathrm{CoCr}_{2} \mathrm{O}_{4}$ formation, showing bad adherence during thermal cycling. 


\section{Keywords}

Cobalt-based alloy

Water vapor

Thermal cycling

\section{Introduction}

For industrial application in molten glasses [1-4], in the presence of a deposit of salt or ashs [5], or for gas turbine applications in moist environments [6-10], cobalt-based alloys are widely used as wear resistant and corrosion-resistant materials. The Phynox cobalt-based alloy $(\mathrm{Co}-$ $20.45 \mathrm{Cr}-15.1 \mathrm{Ni}-14.1 \mathrm{Fe}-7.1 \mathrm{Mo}-1.85 \mathrm{Mn}-0.43 \mathrm{Si}-0.4 \mathrm{Ti} \mathrm{wt} \%$ ) has been developed for high temperature oxidation conditions. Iron additions were found to stabilize the face-centered-cubic form of the cobalt solid solution and to decrease the volume fraction of the primary laves phase [11]. Iron addition induces only minor changes in the corrosion and oxidation resistance. Zhang have studied the oxidation behaviour of a cobalt-based T$800(\mathrm{Co}-17.5 \mathrm{Cr}-28.5 \mathrm{Mo}-3.4 \mathrm{Si} \mathrm{wt} \%)$ exposed isothermally in air, at 800 and $1,000{ }^{\circ} \mathrm{C}[12]$. It was reported that the oxidation mechanism was dependent on the exposure temperature. The oxidation of the alloy followed subparabolic oxidation kinetics at $800{ }^{\circ} \mathrm{C}$. The oxide scale at this temperature exhibited a multi-layered structure including an outer layer of cobalt oxide, a layer composed of complex oxide and spinel, a non-uniform Mo-rich oxide layer, an intermediate mixed-oxide layer and an internal attacked layer with different protrusions into laves phase. During $1,000{ }^{\circ} \mathrm{C}$ exposure, mass gain followed linear kinetics. The oxidation rendered a relatively uniform external Cr-rich oxide layer coupled with a thin layer of spinel on the top surface and voids at the scale/alloy interface and intergranular region together with internal silicon oxide at $1,000{ }^{\circ} \mathrm{C}$. Recent papers deals with the effect of surface damage on the localized reformation of oxide layers. Microindentation data revealed the effects of hightemperature exposure on both the substrate hardness and the oxide scale nature. There were differences in elemental distribution between statically formed oxides and those formed after surface damage [13]. The initial surface pack cementation enrichment in chromium of the Ta-containing alloys, characterized by a maximal content on surface of about $30 \mathrm{wt} \% \mathrm{Cr}$ and a depth of enrichment of several hundreds of micrometers, gives them a 
good resistance to oxidation at $1,200{ }^{\circ} \mathrm{C}$, despite the very low-chromium content in the bulk. This is also due to the interdendritic TaC carbides, which may facilitate outward diffusion of chromium during oxidation as they facilitated its inward diffusion during cementation [14]. On the other hand, a $\mathrm{C}$-free Co-based alloy was submitted to thermal cycling. The eutectic carbides are replaced in this alloy with Mo-rich coarse secondary phase particles dispersed predominantly at interdendritic sites. Its response to thermal cycling is remarkable. The superior thermal fatigue performance of the alloy is attributed to its resistance to high temperature oxidation, to a cobalt-based matrix free of brittle carbides and to its potential to retain its mechanical strength at elevated temperatures [15]. To increase the service temperature of the alloy for corrosion applications, it is important to clarify its high temperature oxidation mechanism. In the present work, the oxidation behaviour of a carbide free cobalt-based Phynox was studied in dry and wet air between 800 and $1,100{ }^{\circ} \mathrm{C}$. Results were obtained concerning isothermal oxidation kinetics during $24 \mathrm{~h}$. Oxides were identified by X-ray diffraction (XRD) and by scanning electron microscopy (SEM) coupled with energy dispersive X-ray spectroscopy (EDX). The effect of service temperature and the scale adherence has been tested by thermal cycling experiments.

Water vapour is a constituent of combustion gases and can affect high temperature corrosion of heat exchangers or engines. Some investigations have been conducted to increase solid oxide fuel cells performance and increase the corrosion resistance of metallic interconnects [16, 17]. Water vapour is also present in power-generation systems and increasing service temperatures leads to heavy corrosion problems. Water vapour effects have already been described in the literature [18-21]. Several studies were conducted on chromia forming alloys [22-26]. Usually, water vapour has a major effect on the growth rate of oxide scales. Increasing the water vapour partial pressure in the atmosphere reduces the time to the onset of breakaway oxidation [27]. Galerie et al. have explained that the breakaway on a $\mathrm{Fe}-15 \% \mathrm{Cr}$ alloy was induced by rapid growth of hematite at the metal/chromia interface, at $800-1,000{ }^{\circ} \mathrm{C}$, in $\mathrm{Ar}-15 \% \mathrm{H}_{2} \mathrm{O}$ [23 ]. But in many cases, the chromia scale failure was attributed to the formation of the $\mathrm{CrO}_{2}(\mathrm{OH})_{2}$ volatile hydroxide [28-30]. Evaporation can lead to the alloy chromium depletion resulting in the formation of an iron-rich non-protective scale. Young proposed that water vapour affects chromia scale growth similarly to what is observed with reactive element metals [31]. Both segregate to oxide grain boundaries. Grain boundary cation diffusion is then 
largely suppressed increasing the oxygen internal diffusion and refining the oxide grain structure. On the other hand, he also explained that in short-term laboratory experiments at temperatures above $800^{\circ} \mathrm{C}$, chromium volatilization could usually be neglected, even in $\mathrm{O}_{2} / \mathrm{H}_{2} \mathrm{O}$ gas mixtures. Refining of the oxide grain structure under wet conditions has also been observed by Jacob et al. after pure chromium oxidation [32]. Recently, Othman et al. proposed that water vapour has no significant effect if a large chromium reservoir induces the growth of a continuous $\mathrm{Cr}_{2} \mathrm{O}_{3}$-scale layer [33]. The ability of $\mathrm{Fe}-\mathrm{Cr}$ alloys to form a protective oxide scale was related to the chromium concentration at the alloy surface. When the concentration of chromium is too low, iron-rich oxides form, inducing breakaway oxidation. Rahmel et al. suggested that an $\mathrm{H}_{2} / \mathrm{H}_{2} \mathrm{O}$ gas mixture can be formed in voids within the scale then facilitating rapid inward transport of oxygen [18]. From the literature review it can be stated that owing to its relatively high chromium content and alloying elements, the Phynox alloy is oxidation resistant at temperatures up to $1,000{ }^{\circ} \mathrm{C}$ in dry environments [34]. Nevertheless, no extensive data are available on cobalt base alloys oxidation in wet environments. Then, the aim of the present work is to determine the effect of water vapour on the oxidation mechanism of the Phynox alloy. The effect of water vapour on the oxide scale adherence will be evaluated by thermal cycling tests between 800 and $1,100{ }^{\circ} \mathrm{C}$ and compared to dry air conditions.

\section{Experimental Procedures}

The substrate material used in the present study is a cobalt-based superalloy (Phynox), provided by ArcellorMittal Imphy. The chemical composition (in $\mathrm{wt} \%$ ) is given in Table 1 . The specimens are $1.6 \mathrm{~mm}$ thick and show a total surface area of around $5 \mathrm{~cm}^{2}$. They were polished on silicon carbide paper up to the 1,200 polishing grade, then washed with ethanol and dried just before oxidation between 800 and $1,100{ }^{\circ} \mathrm{C}$. The kinetic results (TGA) were recorded under isothermal conditions by means of a Setaram TG-DTA 921600 microthermobalance, during $24 \mathrm{~h}$.

\section{Table 1}

Phynox composition in wt $\%$

\begin{tabular}{|l|l|l|l|l|l|l|l|l|l|}
\hline Phynox & Co & Cr & Ni & Fe & Mo & Mn & Si & Al & C \\
\hline Content wt\% & Balance & 20.4 & 15.1 & 14.1 & 7.1 & 1.85 & 0.43 & 0.04 & 0.042 \\
\hline
\end{tabular}


The water vapour experiments were performed in air containing $13 \mathrm{vol} \% \mathrm{H}_{2} \mathrm{O}$. The flowing air $\left(8 \mathrm{~L} \mathrm{~h}^{-1}\right.$ flow rate) is saturated through boiling water. Then, the water bath humidifier maintained at $50{ }^{\circ} \mathrm{C}$ controls the water vapour ratio by condensation of the excess water vapour. All the connecting tubes are maintained at $100{ }^{\circ} \mathrm{C}$ in order to avoid any water condensation. A schematic drawing of the rig was provided in a previous paper of Rolland et al. [35].

Similar gas humidifiers were used either for TGA and thermal cycling tests in a tubular furnace. Dry and wet thermal cycling tests were performed at atmospheric pressure in a tubular furnace adapted for oxidation under dry or wet air. Two samples were placed at the same time into an alumina crucible to estimate the reproducibility. The thermal cycles consist in a $23 \mathrm{~h}$ exposure at high temperature, followed by $1 \mathrm{~h}$ at ambient temperature after air quenching. The weight change of the samples was determined after each cycle by use of a balance with an accuracy of $0.01 \mathrm{mg}$. The characterization of the oxide scales was carried out in an X-ray Philips X' PERT MPD diffractometer (copper radiation, $\lambda \mathrm{K} \alpha=0.15406 \mathrm{~nm}$ ). The XRD conditions were: $2 \Theta$ scan, step $0.02^{\circ}$, range from $10^{\circ}$ to $80^{\circ}, 3 \mathrm{~s}$ counting time. The morphology of the external interface as well as the cross sections, were observed with secondary electrons using a JEOL 7600 Scanning Electron Microscope (SEM). The analysis of the scale was performed with a LINK EDX. The EDX point analyses were performed with an electron probe focused to a $1 \mu \mathrm{m}$ spot.

\section{Results}

\section{Isothermal Oxidation Kinetics}

Isothermal thermogravimetric analyses were carried out during $24 \mathrm{~h}$, at 800 , $900,1000,1100{ }^{\circ} \mathrm{C}$, in dry and wet air $\left(13 \mathrm{vol} \% \mathrm{H}_{2} \mathrm{O}\right)$. The mass gain curves per unit area are given on Fig. 1. During the cobalt-based Phynox oxidation all the kinetic curves follow a parabolic regime. The calculated parabolic rate constants are given in Table 2 . The oxidation rate is always higher in wet environment during the $24 \mathrm{~h}$ oxidation.

\section{Fig. 1}

Mass gain curves obtained during the isothermal cobalt base Phynox oxidation 
between 800 and $1,000^{\circ} \mathrm{C}$, in dry air and in wet air $\left(13 \mathrm{vol} \% \mathrm{H}_{2} \mathrm{O}\right)$

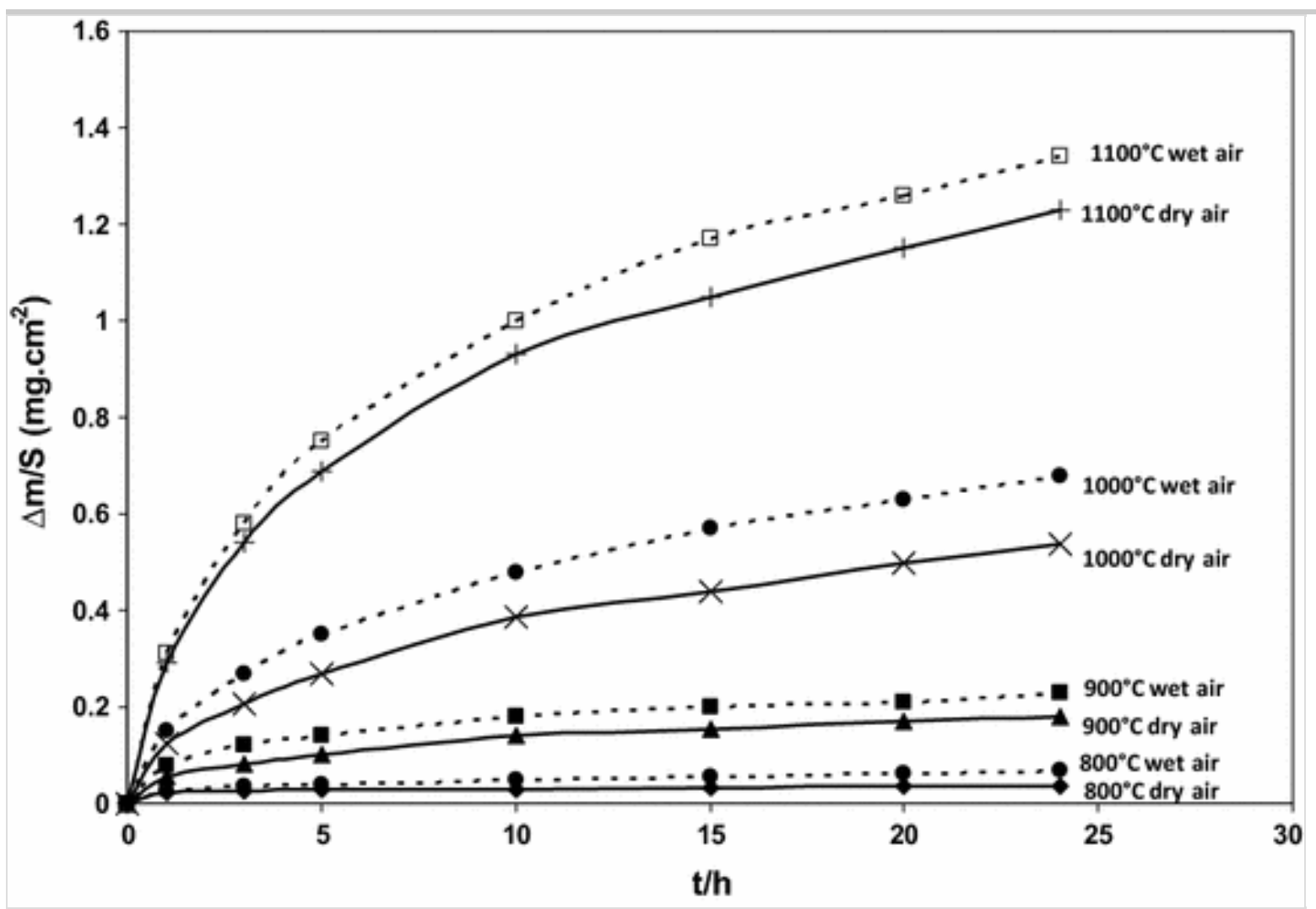

Table 2

Parabolic rate constants for oxidation of a cobalt-based Phynox oxidation in dry air or wet air $\left(13\right.$ vol $\left.\% \mathrm{H}_{2} \mathrm{O}\right)$

\begin{tabular}{|l|l|l|}
\hline \multirow{2}{*}{ Temperature } & Dry air & Wet air \\
\cline { 2 - 3 } & $\mathbf{k p}\left(\mathbf{g}^{\mathbf{2}} \mathbf{c m}^{-\mathbf{4}} \mathbf{s}^{-\mathbf{1}}\right)$ & $\mathbf{k p}\left(\mathbf{g}^{\mathbf{2}} \mathbf{c m}^{-\mathbf{4}} \mathbf{s}^{-\mathbf{1}}\right)$ \\
\hline $800{ }^{\circ} \mathrm{C}$ & $1.68( \pm 0.05) \times 10^{-14}$ & $5.60( \pm 0.05) \times 10^{-14}$ \\
\hline $900{ }^{\circ} \mathrm{C}$ & $3,78( \pm 0.05) \times 10^{-13}$ & $6.10( \pm 0.05) \times 10^{-13}$ \\
\hline $1,000^{\circ} \mathrm{C}$ & $3,20( \pm 0.05) \times 10^{-12}$ & $5.30( \pm 0.05) \times 10^{-12}$ \\
\hline $1,100^{\circ} \mathrm{C}$ & $1,66( \pm 0.05) \times 10^{-11}$ & $2.08( \pm 0.05) \times 10^{-11}$ \\
\hline
\end{tabular}

$\mathrm{AQ2}$

\section{Thermal Cycling Kinetics}

Mass changes registered during thermal cycling tests are shown on Fig. 2 for temperatures between 800 and $1,000^{\circ} \mathrm{C}$. After 10 cycles $(23+1 \mathrm{~h})$, it is observed that water vapour leads to lower weight gains at 900 and $1,000{ }^{\circ} \mathrm{C}$. At $800{ }^{\circ} \mathrm{C}$, the scale remains similarly adherent during the 5 first cycles in 
wet and dry air. After 5 cycles the mass gain registered is higher in wet air due to an increase of the alloy oxidation and a maintained good scale adherence. At $1,100{ }^{\circ} \mathrm{C}$, in dry air, weight losses are registered after 2 cycles due to scale spallation (Fig. 3 ). In wet air, scale spallation also occurred and after 4 cycles the weight losses registered in wet air are very important because the spalled amount increased with the oxide thickness. The scale adherence is then very bad compared with the scale formed in dry air.

\section{Fig. 2}

Mass gain curves obtained during the thermal cycling oxidation of the cobalt base Phynox between 800 and $1,000{ }^{\circ} \mathrm{C}$, in dry air and in wet air $\left(13 \mathrm{vol} \% \mathrm{H}_{2} \mathrm{O}\right) .23+1 \mathrm{~h}$ thermal cycles

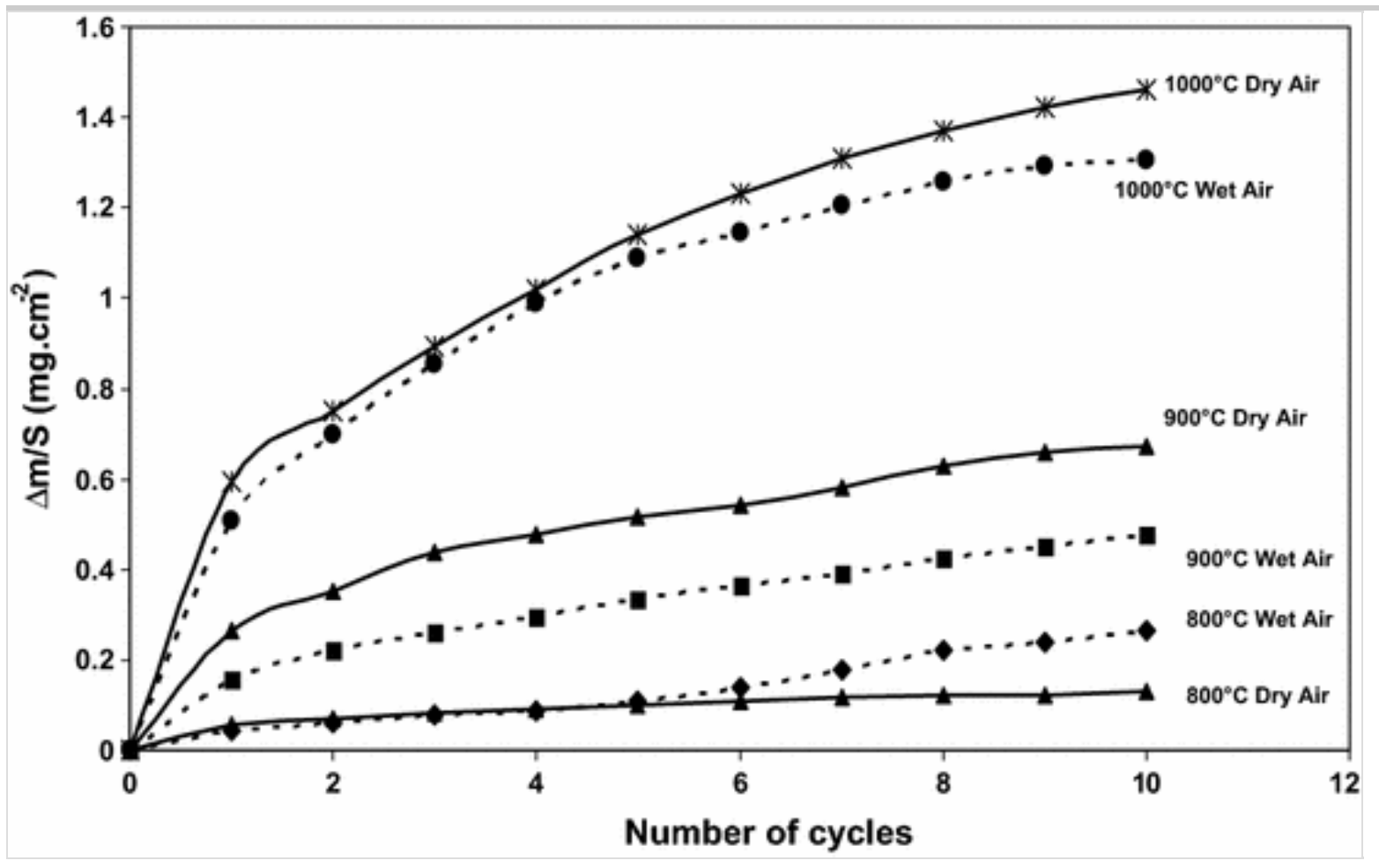

Fig. 3

Mass loss curves obtained during thermal cycling oxidation of the cobalt base Phynox at $1,100{ }^{\circ} \mathrm{C}$, in dry air and in wet air $\left(13\right.$ vol $\left.\% \mathrm{H}_{2} \mathrm{O}\right) .23+1 \mathrm{~h}$ thermal cycles 


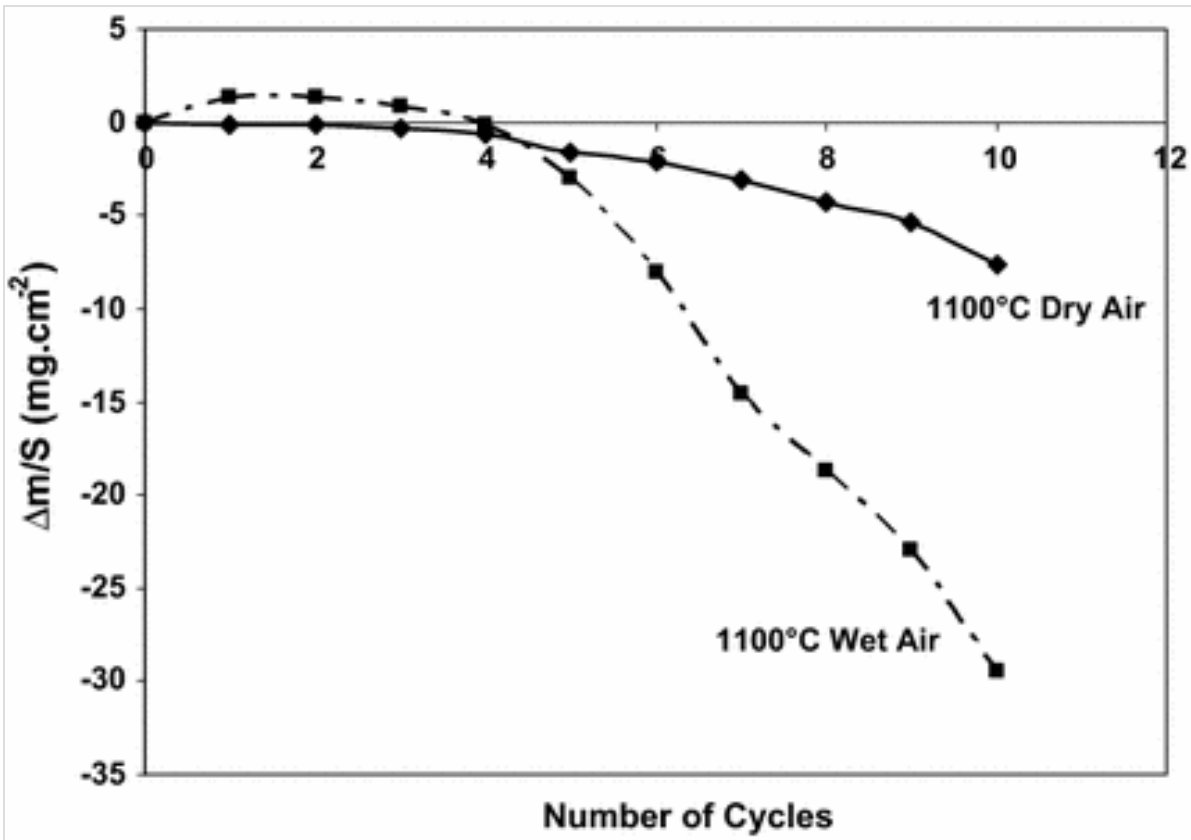

\section{XRD Results After Isothermal Oxidation}

The oxide scale formed on the Phynox alloy after $24 \mathrm{~h}$ isothermal oxidation in dry air was analyzed by XRD on the metallic substrate after cooling to room temperature (Fig. 4). The XRD patterns show the presence of $\mathrm{Mn}_{1.5} \mathrm{Cr}_{1.5} \mathrm{O}_{4}$ (ICDD 33-0892) and $\mathrm{Cr}_{2} \mathrm{O}_{3}$ (ICDD 38-1479). It appears that both oxides are present simultaneously on the specimen surface. The relatively high $\mathrm{Mn}_{1.5} \mathrm{Cr}_{1.5} \mathrm{O}_{4}$ peaks intensity is not due to a higher proportion of this oxide in the scale but to the location of this oxide at the external interface. The underlying alloy diffraction peaks are less intense as temperature increases because the oxide scale is thicker.

\section{Fig. 4}

XRD patterns obtained on the Phynox specimens oxidized at $800,900,1,000$, $1,100{ }^{\circ} \mathrm{C}$, in air, after $24 \mathrm{~h}$ 


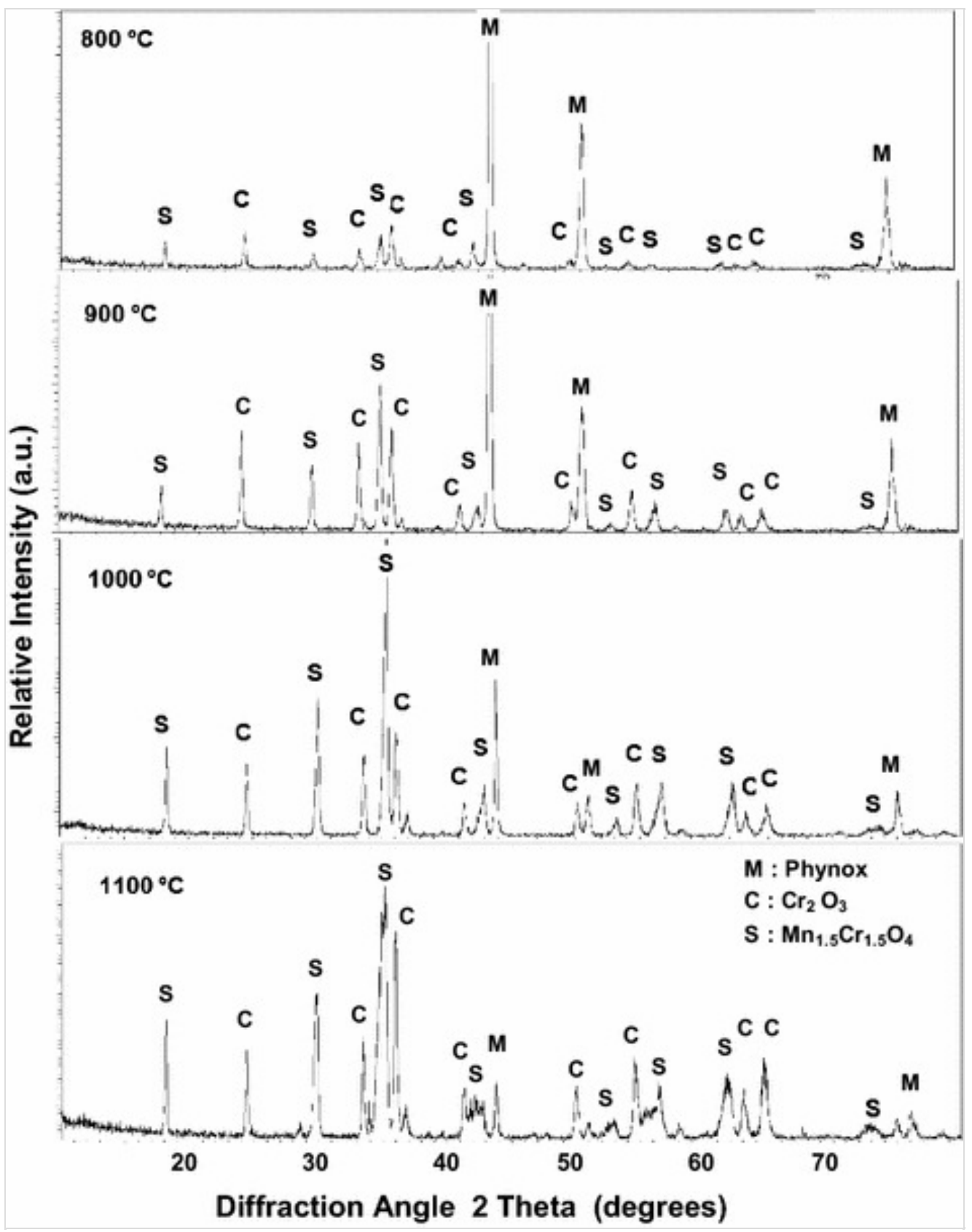

The oxide scale formed on the Phynox alloy after $24 \mathrm{~h}$ isothermal oxidation in wet air $\left(13 \mathrm{vol} \% \mathrm{H}_{2} \mathrm{O}\right)$ was analyzed by XRD on the metallic substrate after cooling to room temperature (Fig. 5). The spinel type $\mathrm{Mn}_{1.5} \mathrm{Cr}_{1.5} \mathrm{O}_{4}$ (ICDD 33-0892) and $\mathrm{Cr}_{2} \mathrm{O}_{3}$ (ICDD 38-1479) are present on the specimen surface. Between 800 and $1,000{ }^{\circ} \mathrm{C}$ no difference can be pointed out between the oxide scale structures identified after dry and wet air oxidation after $24 \mathrm{~h}$. In dry air, the spinel phase is still present on the specimen's surface. In wet air $\left(13 \mathrm{vol} \% \mathrm{H}_{2} \mathrm{O}\right)$, chromia is the main phase detected on the specimen surface after oxidation at $1,100{ }^{\circ} \mathrm{C}$. This is either due to the spinel oxide spallation after cooling to room temperature or rather sluggish spinel scale formation in wet air.

Fig. 5 
XRD patterns obtained on the Phynox specimens oxidized at $800,900,1,000$, $1,100{ }^{\circ} \mathrm{C}$, in wet air $\left(13 \mathrm{vol} \% \mathrm{H}_{2} \mathrm{O}\right)$, after $24 \mathrm{~h}$

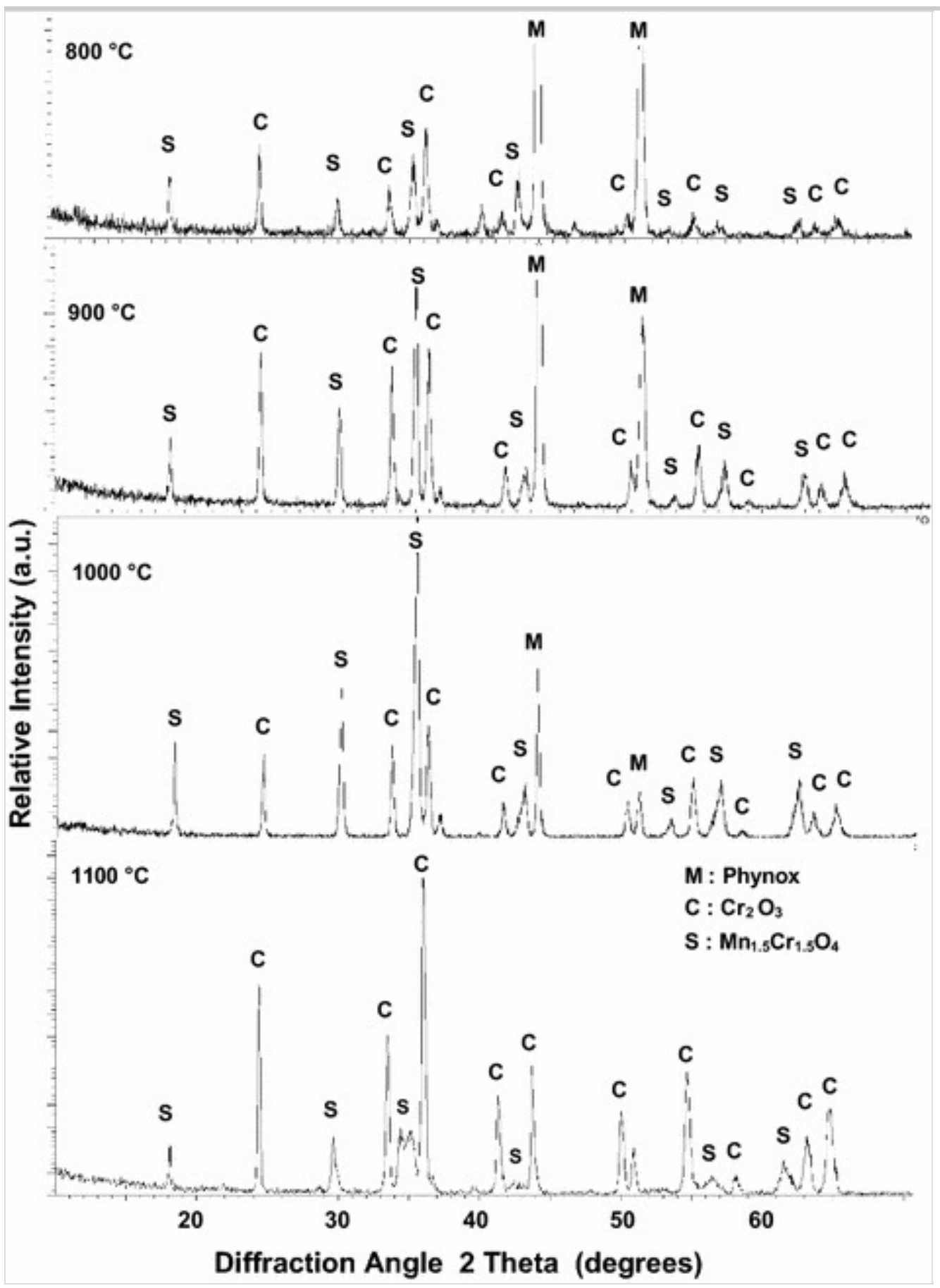

\section{XRD Results After Thermal Cycles}

In dry air, after 10 thermal cycles at $800,900,1,000{ }^{\circ} \mathrm{C}$, chromia $\mathrm{Cr}_{2} \mathrm{O}_{3}$ (ICDD 38-1479) is well detected in the oxide scale (Fig. 6). The spinel phase is mainly composed of $\mathrm{Mn}_{1.5} \mathrm{Cr}_{1.5} \mathrm{O}_{4}$ (ICDD 33-0892). After 10 thermal cycles, in dry air, at $1,100{ }^{\circ} \mathrm{C}$, the scale is composed of $\mathrm{CoCr}_{2} \mathrm{O}_{4}$ (ICDD 22-1084) and $\mathrm{CoMoO}_{4}$ (ICDD 25-1434). $\mathrm{Cr}_{2} \mathrm{O}_{3}$ (ICDD 38-1479) is also detected by XRD. These oxides differ from those formed at low 
temperatures.

Fig. 6Figure 6 should correspond to DRY CONDITIONS as indicated in the text.

As it is presented, the caption and the figure correspond to figure 7.

You should replace figure 6 by figure 7 (with there captions).

XRD patterns obtained on the Phynox specimens oxidized at 800, 900, 1,000, $1,100{ }^{\circ} \mathrm{C}$, in wet air $\left(13 \mathrm{vol}^{\circ} \mathrm{H}_{2} \mathrm{O}\right)$, after 10 cycles $(23+1 \mathrm{~h})$

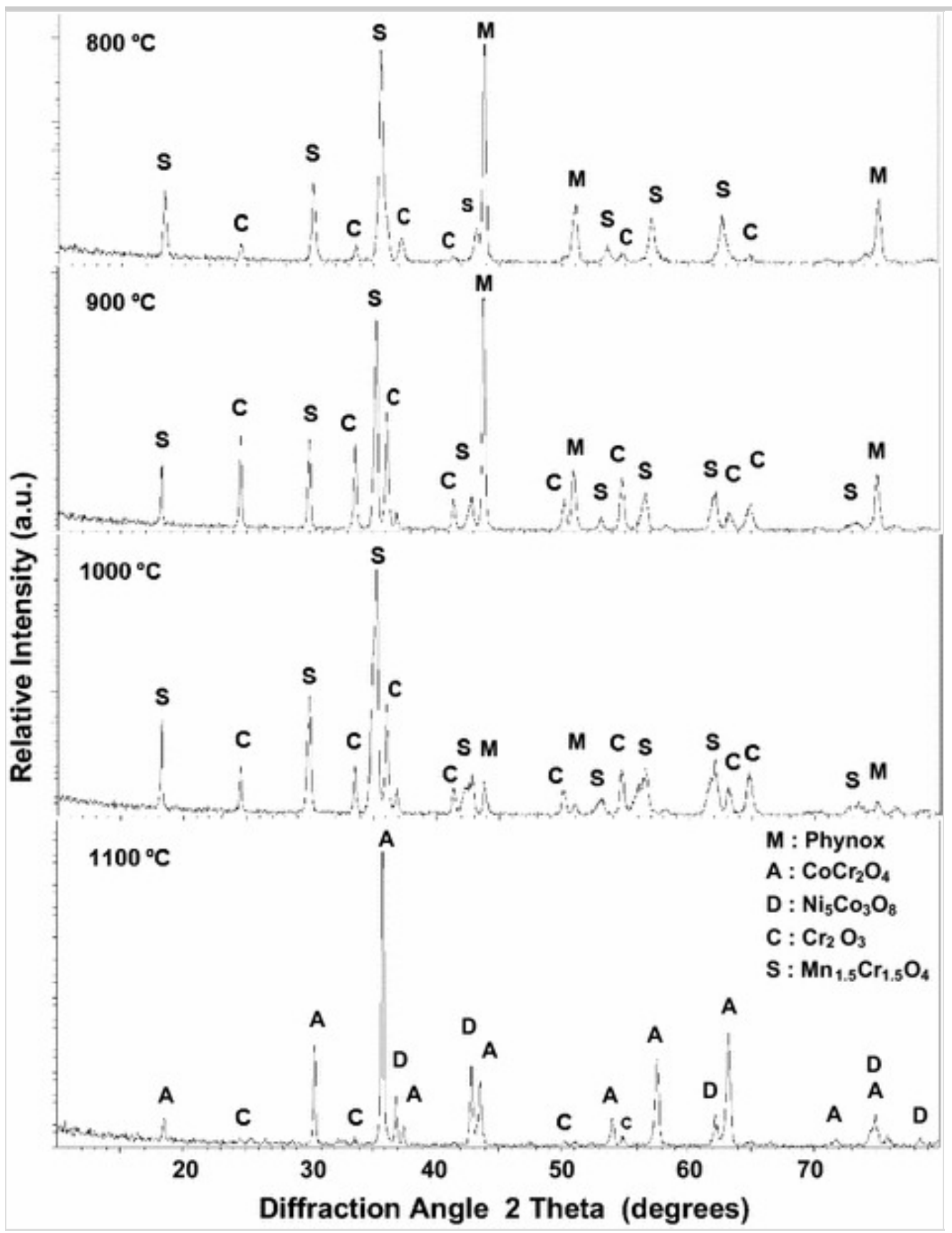

In wet air $\left(13 \mathrm{vol}_{0} \mathrm{H}_{2} \mathrm{O}\right)$, after 10 thermal cycles at $900,1,000{ }^{\circ} \mathrm{C}$, chromia $\mathrm{Cr}_{2} \mathrm{O}_{3}$ (ICDD 38-1479) is detected on the specimen's surface (Fig. 7). The spinel phase is composed of $\mathrm{Mn}_{1.5} \mathrm{Cr}_{1.5} \mathrm{O}_{4}$ (ICDD 33-0892) at 900 and 
$1,000{ }^{\circ} \mathrm{C}$. After 10 cycles at $800{ }^{\circ} \mathrm{C}$ XRD and EDX analyses of the scale cross section show that some chromia grains are mixed with a spinel phase $\mathrm{M}_{3} \mathrm{O}_{4}$ containing: 15 at. $\% \mathrm{Cr} ; 10$ at. $\% \mathrm{Fe} ; 13$ at. $\% \mathrm{Co} ; 3$ at. $\% \mathrm{Mn} ; 2$ at $\% \mathrm{Ni}$; 57 at. $\% \mathrm{O}$. The presence of these elements in the spinel oxide is related to the higher mass gain registered after 5 cycles at $800{ }^{\circ} \mathrm{C}$ in wet air (Fig. 2).

Fig. 7

XRD patterns obtained on the Phynox specimens oxidized at $800,900,1,000$, $1,100{ }^{\circ} \mathrm{C}$, in air, after $10(23+1 \mathrm{~h})$ cycles

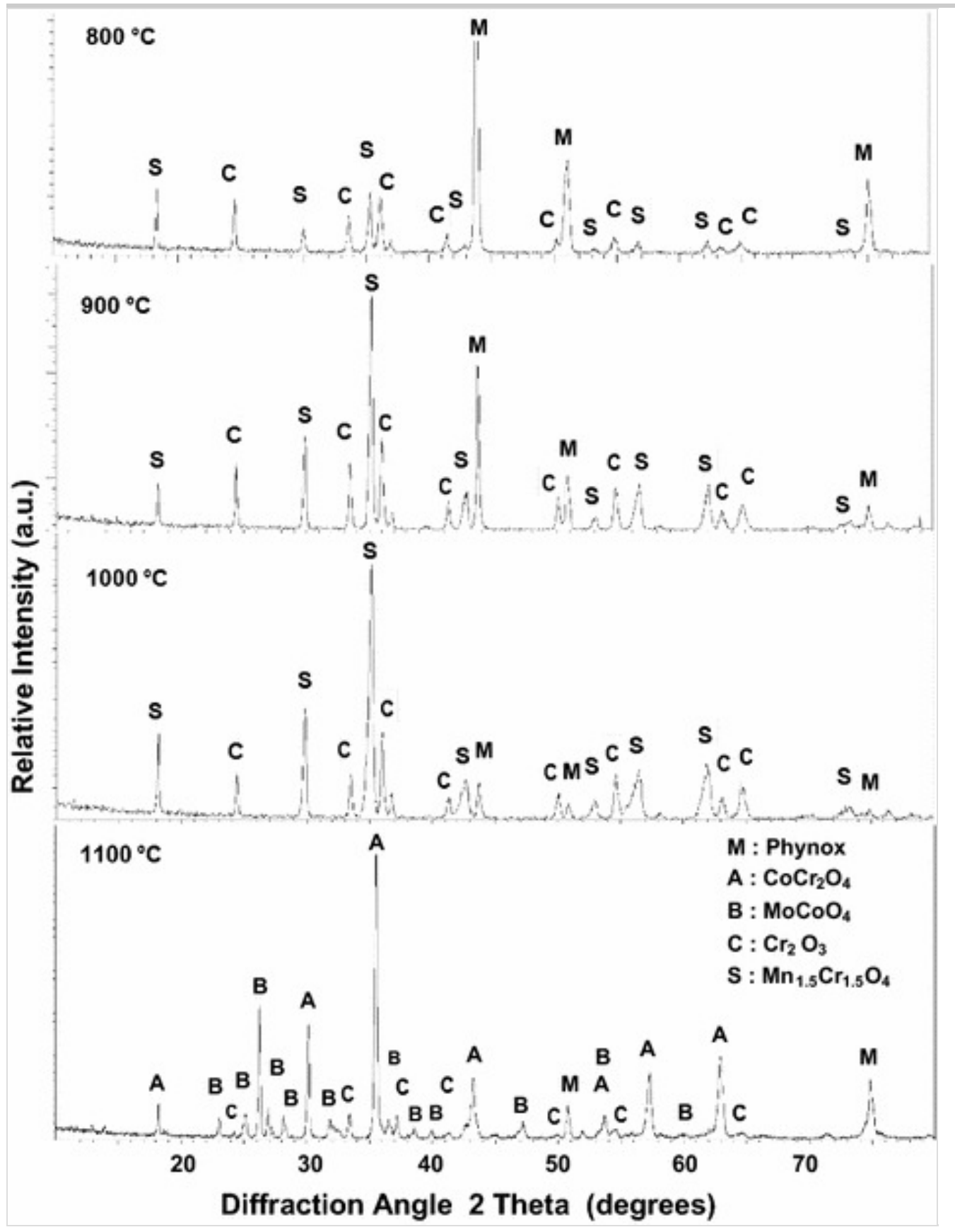

After 10 thermal cycles at $1,100{ }^{\circ} \mathrm{C}$ in wet air $\left(13\right.$ vol $\left.\% \mathrm{H}_{2} \mathrm{O}\right)$, oxides detected on the surface vary from those observed at low temperatures or detected in dry atmosphere. The scale is composed of $\mathrm{CoCr}_{2} \mathrm{O}_{4}$ (ICDD 22- 
1084) and $\mathrm{Ni}_{5} \mathrm{Co}_{3} \mathrm{O}_{8}$ (ICDD 03-0986). $\mathrm{Cr}_{2} \mathrm{O}_{3}$ (ICDD 38-1479) is not easily detected by XRD due to its location at the internal interface under a thick oxide scale. Compared to thermal cycling tests performed in dry air, water vapour leads to a scale containing $\mathrm{Ni}_{5} \mathrm{Co}_{3} \mathrm{O}_{8}$. In such conditions the molybdenum containing mixed oxide $\mathrm{CoMoO}_{4}$ is not observed because this oxide usually located at the external interface has spalled off during the thermal cycling. The oxidation of nickel giving rise to $\mathrm{Ni}_{5} \mathrm{Co}_{3} \mathrm{O}_{8}$ is due to the high chromium depletion in the alloy located under the oxide scale $(7 \mathrm{wt} \%$ $\mathrm{Cr}$ instead of $20.4 \mathrm{wt} \% \mathrm{Cr}$ initially present in the alloy composition).

\section{Oxide Scale Morphology}

\section{Surface Analysis}

For each temperature the surface morphology of the scale formed on the Phynox specimens after $24 \mathrm{~h}$ isothermal oxidation, in dry air and wet air $\left(13 \mathrm{vol} \% \mathrm{H}_{2} \mathrm{O}\right)$, is presented on Fig. 8. No scale spallation is observed on the surface obtained at 800 and 900 and $1,000{ }^{\circ} \mathrm{C}$. At $1,100{ }^{\circ} \mathrm{C}$ parts of the external $\mathrm{Mn}_{1.5} \mathrm{Cr}_{1.5} \mathrm{O}_{4}$ scale spalled off during cooling, especially after wet air oxidation. The spallation of the external spinel $\mathrm{Mn}_{1.5} \mathrm{Cr}_{1.5} \mathrm{O}_{4}$ subscale occurred but the internal chromia scale remains adherent on the surface.

\section{Fig. 8}

SEM micrograph showing the morphology on the Phynox surface oxidized at $800,900,1,000$ and $1,100{ }^{\circ} \mathrm{C}$, in air and in wet air $\left(13\right.$ vol $\left.\% \mathrm{H}_{2} \mathrm{O}\right)$, after $24 \mathrm{~h}$ 


\section{Dry Air}

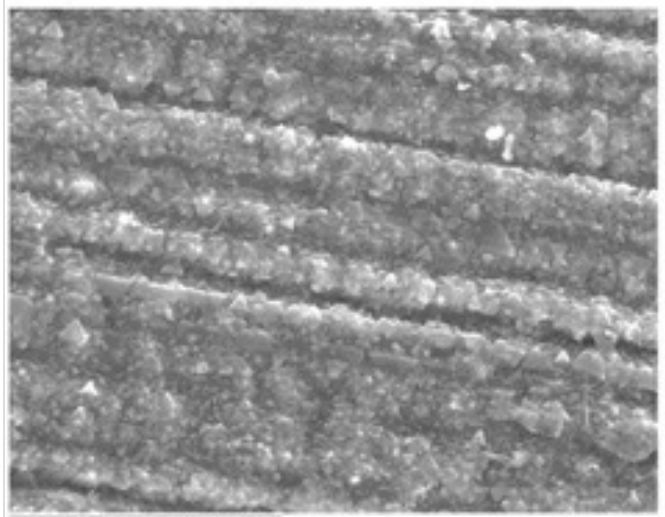

$10 \mu \mathrm{m}$

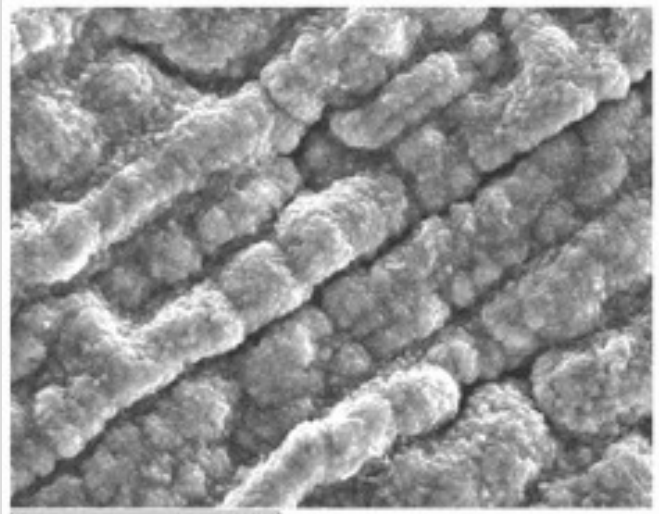

$10 \mu \mathrm{m}$

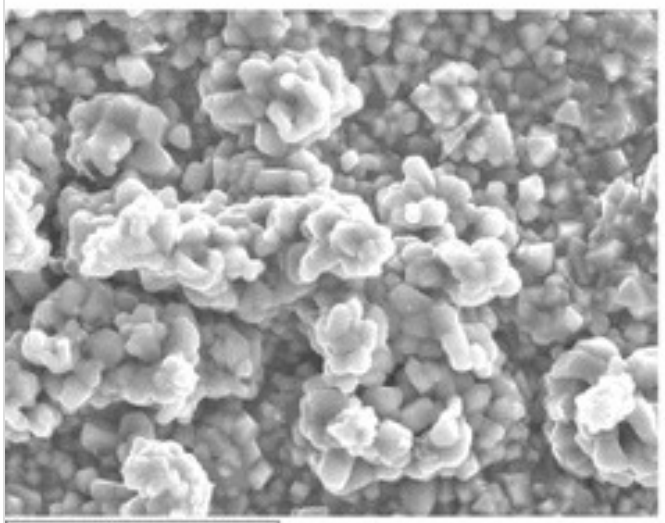

$10 \mu \mathrm{m}$

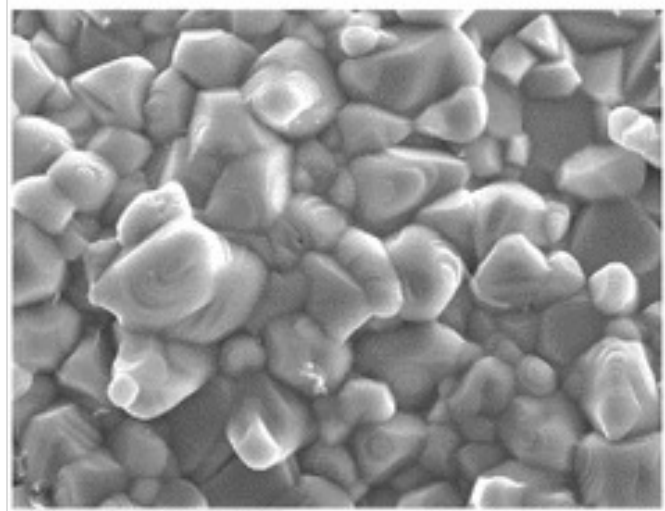

$10 \mu \mathrm{m}$
Wet Air (13 vol. $\left.\% \mathrm{H}_{2} \mathrm{O}\right)$

$800^{\circ} \mathrm{C}$

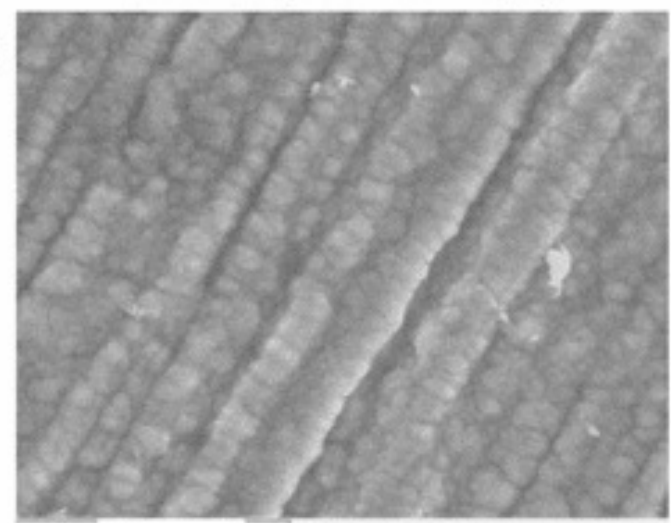

$10 \mu \mathrm{m}$

$900^{\circ} \mathrm{C}$

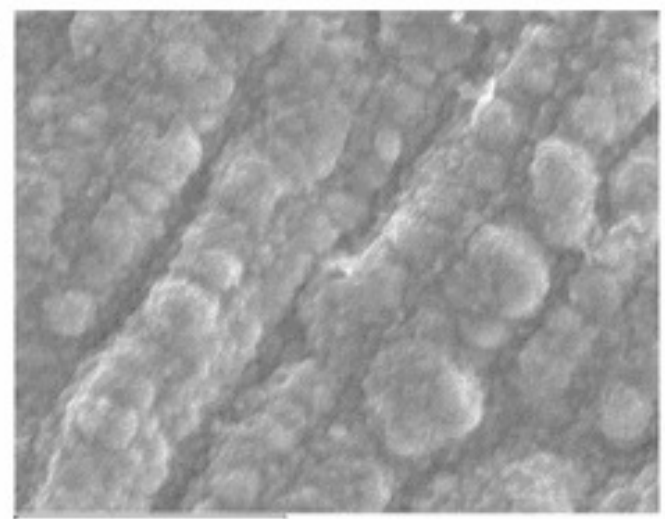

$10 \mu \mathrm{m}$

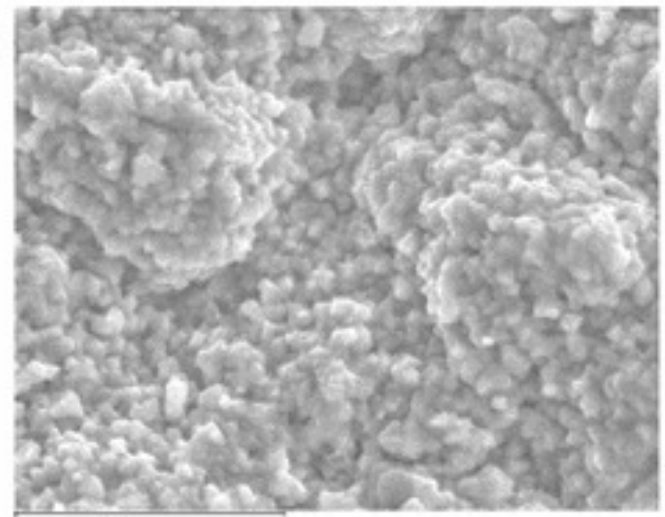

$10 \mu \mathrm{m}$

$1100^{\circ} \mathrm{C}$

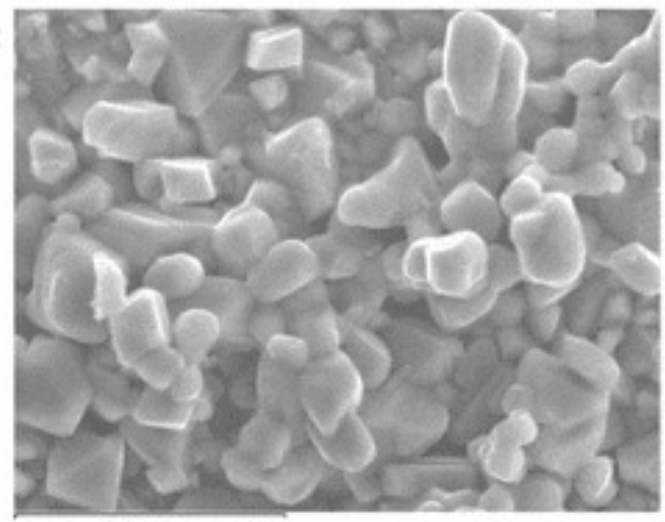

$10 \mu \mathrm{m}$

In order to analyze the scale composition, EDX analyses of the sample surfaces were performed. It shows the presence of manganese, chromium, 
and oxygen in the outer $\mathrm{Mn}_{1.5} \mathrm{Cr}_{1.5} \mathrm{O}_{4}$ remaining particles. EDX exhibits the presence of oxygen and chromium in the adherent subscale mainly composed of $\mathrm{Cr}_{2} \mathrm{O}_{3}$.

\section{Cross-Section Morphology}

After $24 \mathrm{~h}$ isothermal oxidation in dry and wet air $\left(13 \mathrm{vol} \% \mathrm{H}_{2} \mathrm{O}\right)$, SEM examinations were carried out on the specimen cross sections in order to estimate the subscale thickness and to identify the elements incorporated in the oxide scale (Fig. 9). After $24 \mathrm{~h}$ oxidation at $800{ }^{\circ} \mathrm{C}$, the adherent scale is about $1 \mu \mathrm{m}$ thick. The thin scale is composed of $\mathrm{Mn}_{1.5} \mathrm{Cr}_{1.5} \mathrm{O}_{4}$ and $\mathrm{Cr}_{2} \mathrm{O}_{3}$ mixed together. This temperature $\left(800{ }^{\circ} \mathrm{C}\right)$ appears to be too low to lead to a continuous chromia scale formation. The black spots at the internal interface correspond to $\mathrm{SiO}_{2}$ precipitates. The white nodules inside the alloy are molybdenum-containing intermetallic phases. After $24 \mathrm{~h}$ oxidation at $900{ }^{\circ} \mathrm{C}$, the scale is about $4 \mu \mathrm{m}$ thick. The manganese containing oxide is detected at the air/oxide interface. The main scale is composed of $\mathrm{Cr}_{2} \mathrm{O}_{3} . \mathrm{SiO}_{2}$ is present at the internal interface and inside the alloy. After oxidation at $1,000{ }^{\circ} \mathrm{C}, \mathrm{EDX}$ analyses show the presence of a $\mathrm{Mn}_{1.5} \mathrm{Cr}_{1.5} \mathrm{O}_{4}$ subscale at the external interface over an $8 \mu \mathrm{m}$ thick $\mathrm{Cr}_{2} \mathrm{O}_{3}$ scale. Internal silica particles seem to be located preferably in front of the internal chromia protrusion. Cobalt is not present in the oxides formed under such conditions. After isothermal oxidation at $1,100{ }^{\circ} \mathrm{C}, \mathrm{EDX}$ analyses show the presence of manganese at the external interface where it has not spalled off. The main scale is composed of $11 \mu \mathrm{m}$ thick $\mathrm{Cr}_{2} \mathrm{O}_{3}$ scale. Silica is observed at the internal interface and along the alloy grain boundaries. No cobalt was detected inside the oxide scale. Between 800 and $1,100{ }^{\circ} \mathrm{C}$ the oxide scale cross-section structure indicates that internal oxidation contributes to the scale formation.

\section{Fig. 9}

SEM cross sections showing the morphology on the Phynox specimens oxidized at $800,900,1,000$ and $1,100{ }^{\circ} \mathrm{C}$, in dry air (left), and in wet air (right) $\left(13 \mathrm{vol} \% \mathrm{H}_{2} \mathrm{O}\right)$ after $24 \mathrm{~h}(\mathrm{BSE} \times 7,000$ and $\times 3,000)$ 
Dry Air

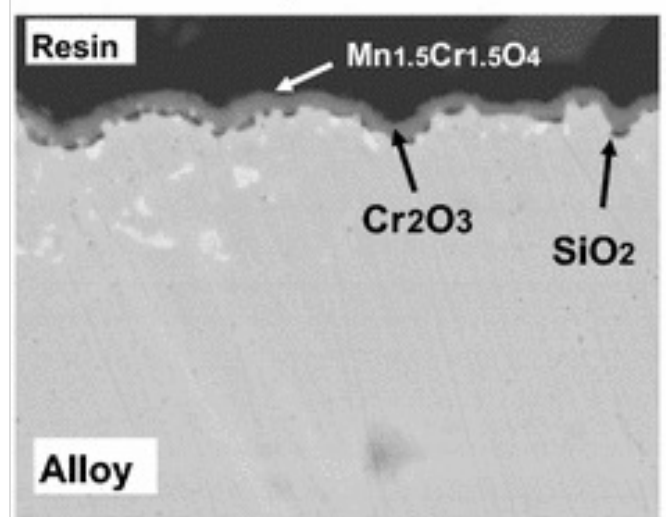

$8 \mu \mathrm{m}$

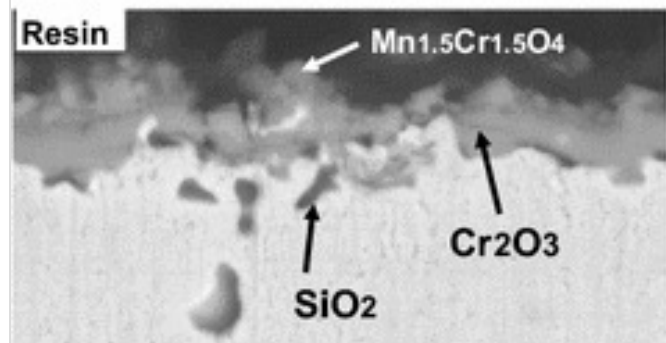

Alloy

$8 \mu \mathrm{m}$

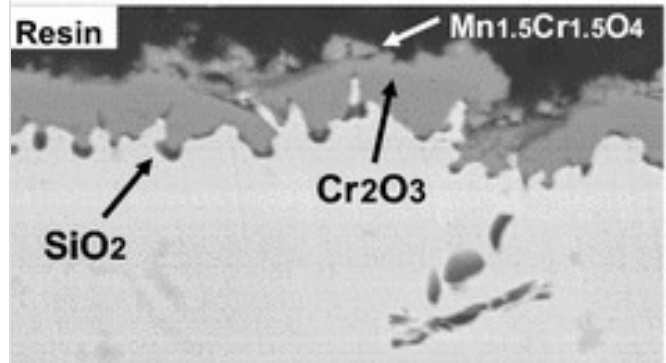

Alloy

$10 \mu \mathrm{m}$

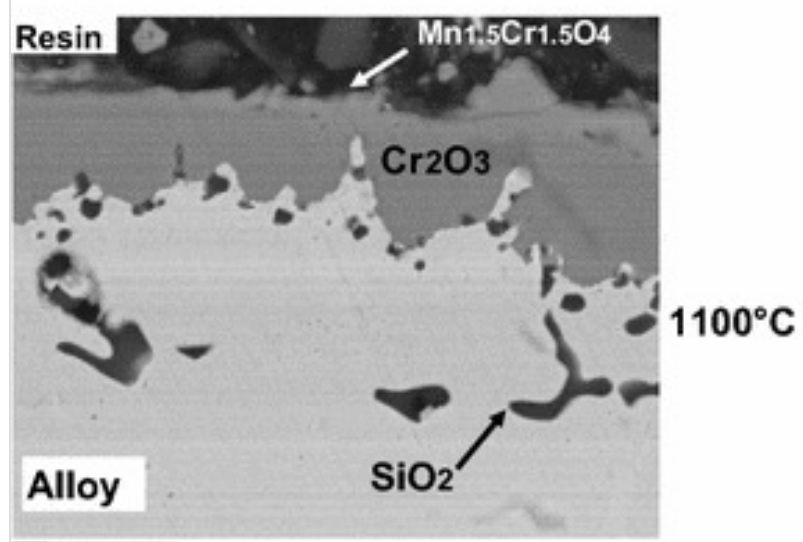

$10 \mu \mathrm{m}$

$900^{\circ} \mathrm{C}$

$1000^{\circ} \mathrm{C}$
Wet Air (13 vol\%H2O)
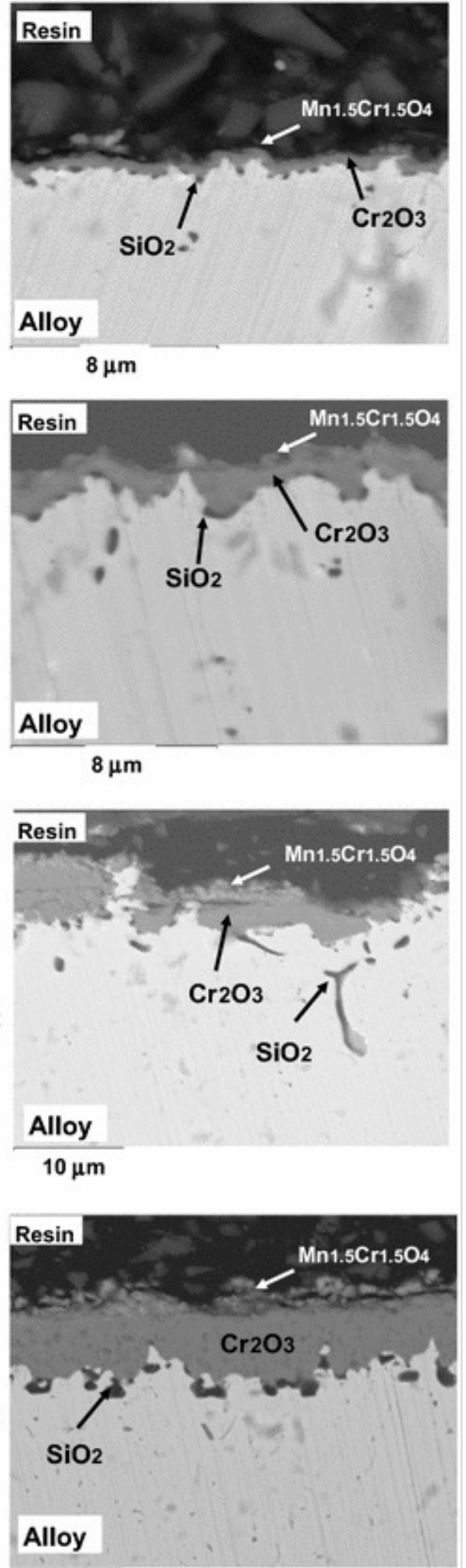

$10 \mu \mathrm{m}$

Water vapour induces some modifications in the scale structure after $24 \mathrm{~h}$ isothermal oxidation. After wet air oxidation, it appears that porosities are 
observed inside the chromia scale and the surface grain size is decreased. Silica is more present at the internal interface and less inside the alloy grain boundaries after oxidation in wet air at $1,100^{\circ} \mathrm{C}$. It then indicates that the outward silicon diffusion in the alloy is promoted or inward oxygen diffusion is favoured.

\section{Surface Analysis After Thermal Cycling}

For each temperature the surface morphology of the scale formed on the Phynox specimens after 10 cyles $(23+1 \mathrm{~h})$, in dry air and wet air $\left(13 \mathrm{vol} \% \mathrm{H}_{2} \mathrm{O}\right.$ ), is presented on Fig. 10 . No scale spallation is observed on the surface obtained at $800{ }^{\circ} \mathrm{C}$. More oxide nodules are observed on the surface after wet air thermal cycling at $800{ }^{\circ} \mathrm{C}$ due to the additional oxidation of iron and cobalt. At $900{ }^{\circ} \mathrm{C}$ the scale is composed of chromia and manganese chromite. This figure shows that at $900{ }^{\circ} \mathrm{C}$ only manganese chromite particles spalled off at the external interface and chromia remains adherent. At $1,000{ }^{\circ} \mathrm{C}$, more scale spallation and vaporization occured during wet air cycling. Spallation mainly concerns the external spinel subscale. The inner chromia scale remains adherent on the surface. After 10 cycles at $1,100{ }^{\circ} \mathrm{C}$ under dry and wet air the surface is rough. Scale spallation and reoxidation occurred after each cycle. The main surface is covered by a $\mathrm{CoCr}_{2} \mathrm{O}_{4}$ scale and the biggest crystals observed on the surface micrograph correspond to $\mathrm{Ni}_{5} \mathrm{Co}_{3} \mathrm{O}_{8}$ after 10 wet air cycles and to $\mathrm{CoMoO}_{4}$ after 10 cycles in dry air.

\section{Fig. 10}

SEM micrograph showing the morphology on the Phynox surface oxidized at $800,900,1,000$ and $1,100{ }^{\circ} \mathrm{C}$, in air and in wet air $\left(13 \mathrm{vol} \% \mathrm{H}_{2} \mathrm{O}\right)$, after 10 $(23+1 \mathrm{~h})$ thermal cycles 


\section{Dry Air}

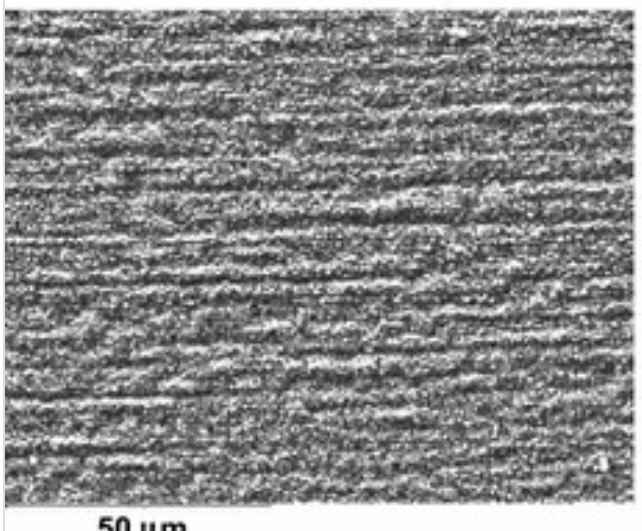

$50 \mu \mathrm{m}$

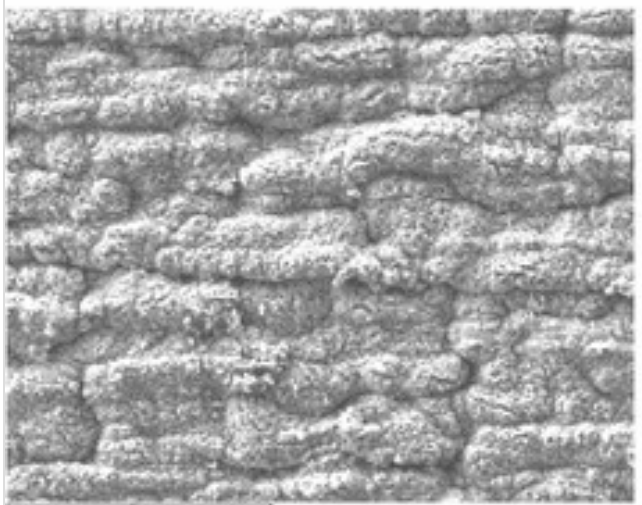

$50 \mu \mathrm{m}$
Wet Air (13 vol\% $\mathrm{H}_{2} \mathrm{O}$ )

$800^{\circ} \mathrm{C}$

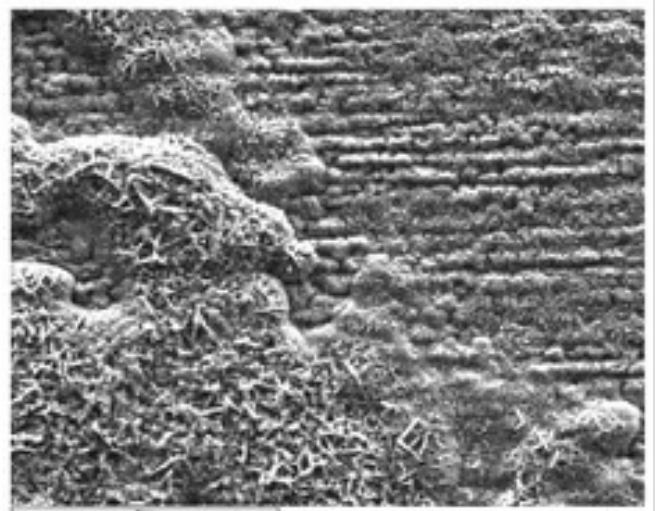

$50 \mu \mathrm{m}$

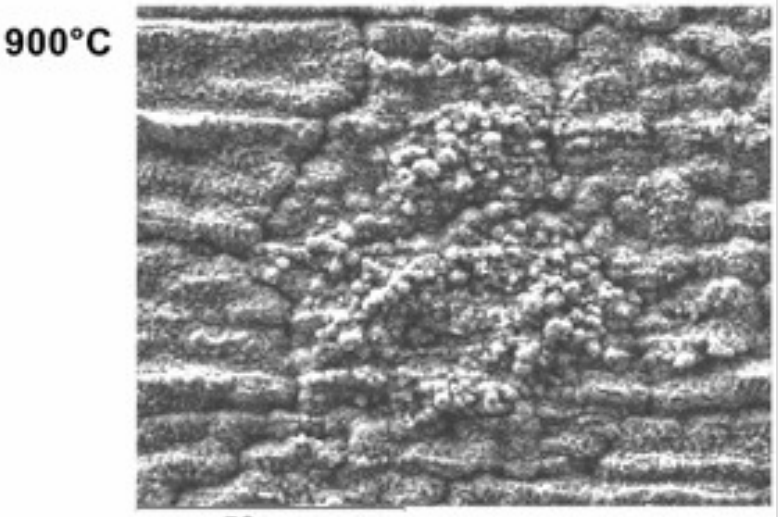

$50 \mu \mathrm{m}$

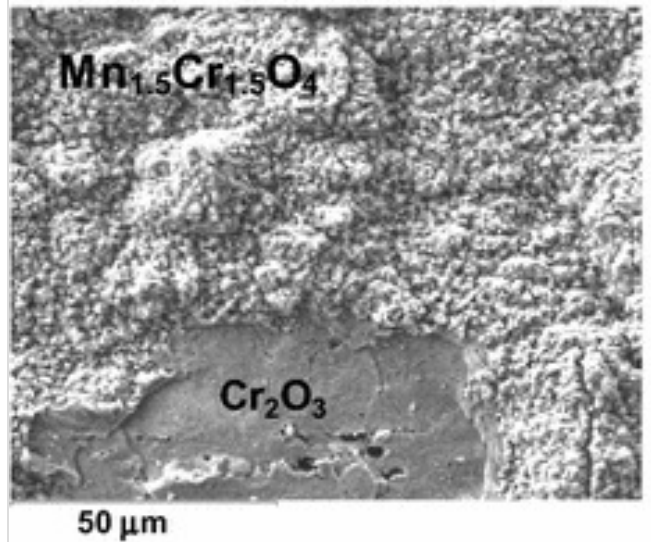

$1000^{\circ} \mathrm{C}$
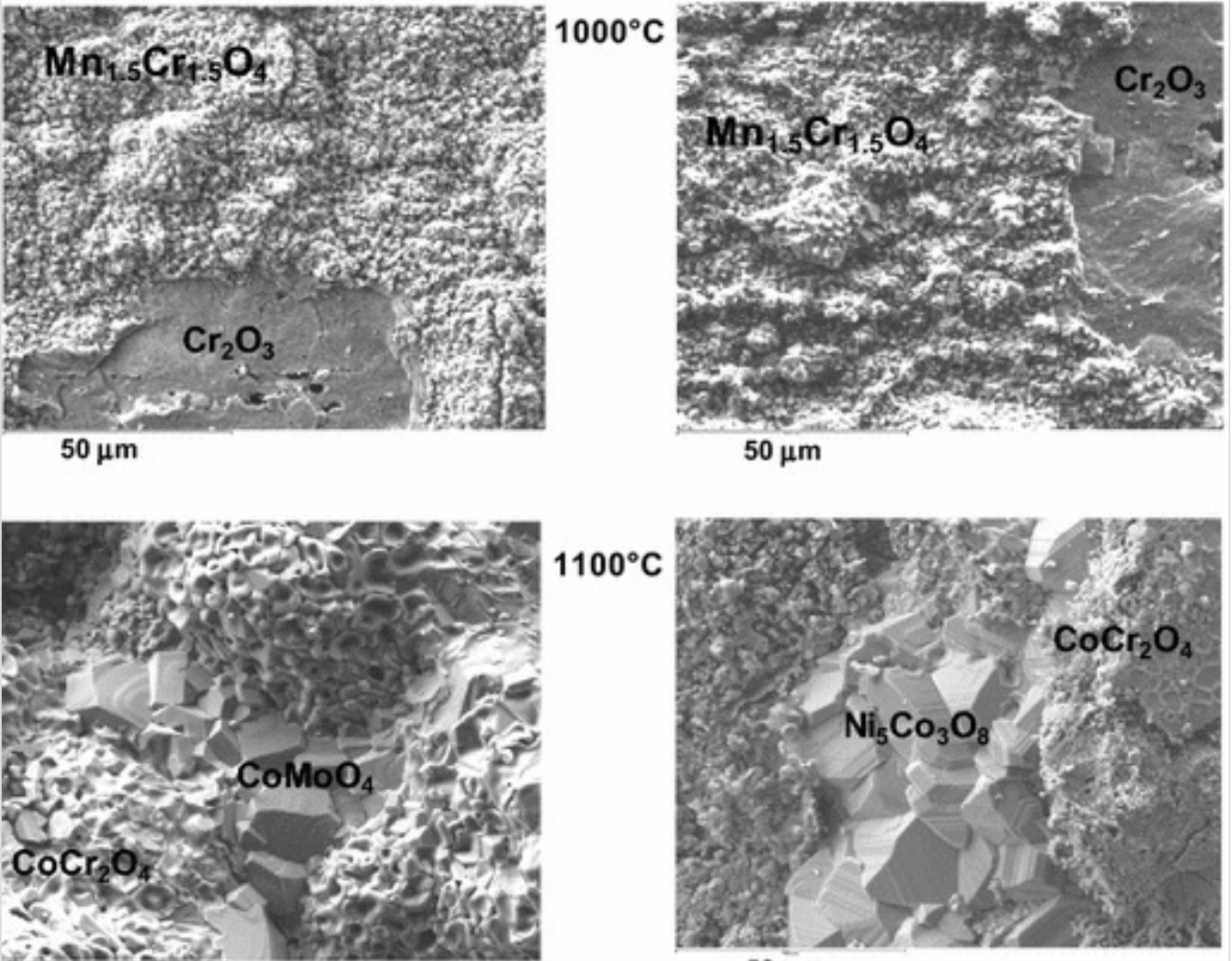

$50 \mu \mathrm{m}$

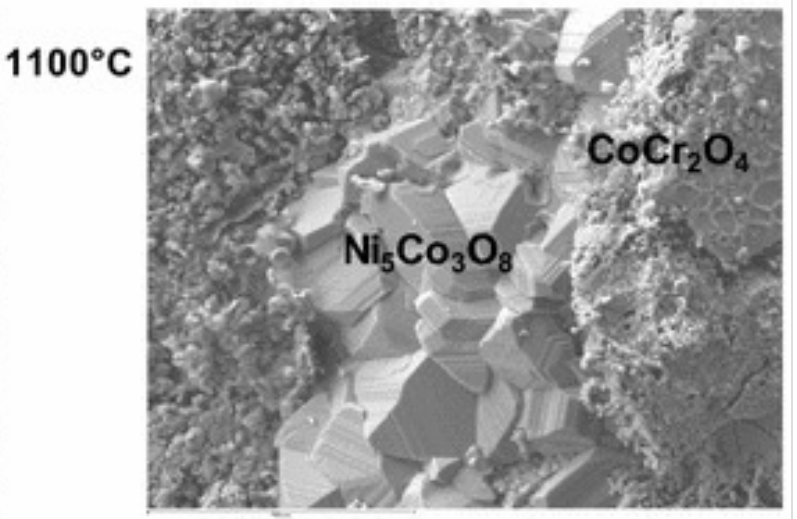

$50 \mu \mathrm{m}$

\section{Cross-Section Morphology After Thermal Cycling}

After cyclic oxidation, SEM-EDX analyses were carried out on the specimen 
cross-sections to obtain the oxide scale composition (Fig. 11). After 10 thermal cycles at 800 and $900{ }^{\circ} \mathrm{C}$ in dry or wet air, the cross sections show that the oxide scale is adherent. At $800{ }^{\circ} \mathrm{C}$ chromia is mixed with a spinel phase containing : 15 at. $\% \mathrm{Cr} ; 10$ at. $\% \mathrm{Fe} ; 13$ at.\% Co; 3 at. $\% \mathrm{Mn} ; 2$ at. $\%$ $\mathrm{Ni} ; 57$ at. $\%$ O. At $900{ }^{\circ} \mathrm{C}$, the oxide scale is composed of manganese chromite and chromia. At $900{ }^{\circ} \mathrm{C}$, the black spots located in the metal close the internal interface correspond to the internal silica formation. After 10 thermal cycles at $1,000{ }^{\circ} \mathrm{C}$ in dry and wet air, the cross section shows that the scale is composed of an outer manganese chromite oxide subscale and an inner $\mathrm{Cr}_{2} \mathrm{O}_{3}$ scale. Cobalt, iron and molybdenum are not present in the corrosion products after cycling at $1,000{ }^{\circ} \mathrm{C}$. Along the alloy grain boundaries, the black areas located $20 \mu \mathrm{m}$ deep inside correspond to the internal oxidation of silicon.

\section{Fig. 11}

SEM cross sections showing the morphology on the Phynox specimens oxidized at $800,900,1,000$ and $1,100{ }^{\circ} \mathrm{C}$, in dry air (left), and in wet air (right) $\left(13 \mathrm{vol}^{\circ} \mathrm{H}_{2} \mathrm{O}\right)$ after $10(23+1 \mathrm{~h})$ cycles 
Wet Air (13 vol\% $\left.\mathrm{H}_{2} \mathrm{O}\right)$
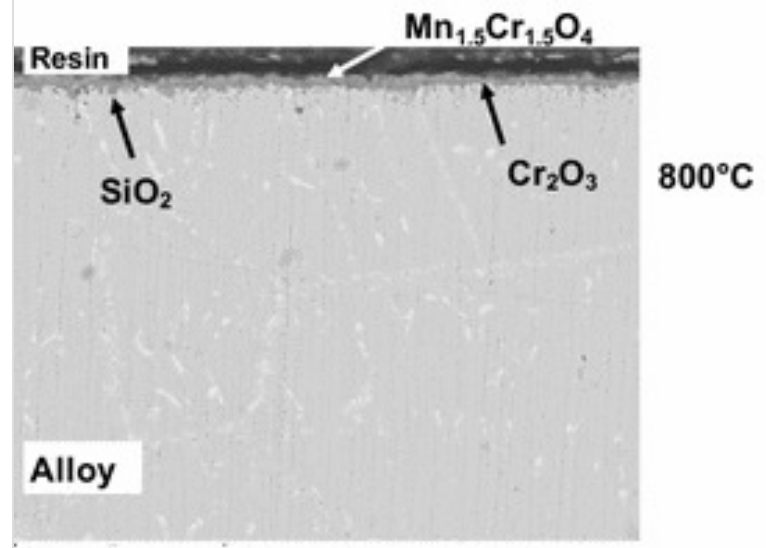

Spinel $\left(\mathrm{CrCo}_{0.93} \mathrm{Fe}_{0.72} \mathrm{Mn}_{0.21} \mathrm{Ni}_{0.14} \mathrm{O}_{4}\right)$

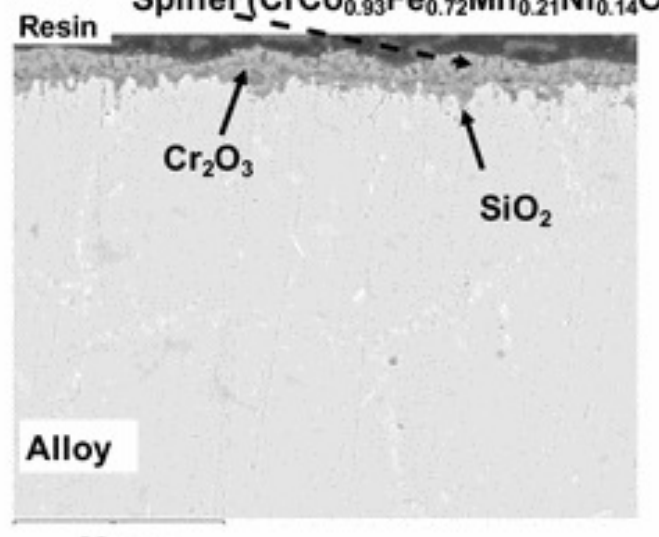

$20 \mu \mathrm{m}$

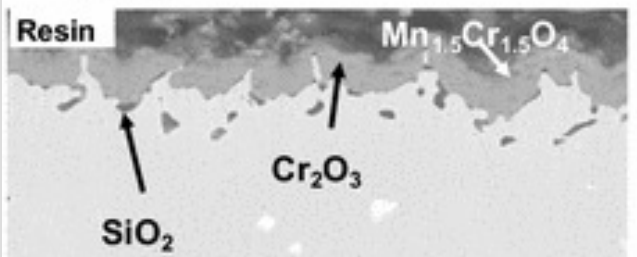

$900^{\circ} \mathrm{C}$

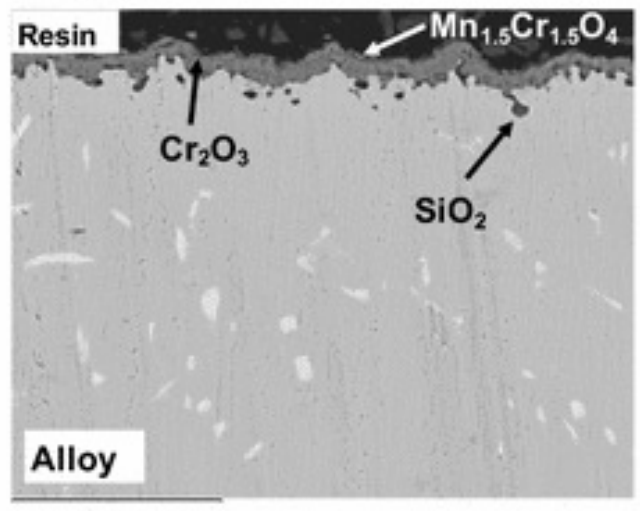

$20 \mu \mathrm{m}$

$20 \mu \mathrm{m}$
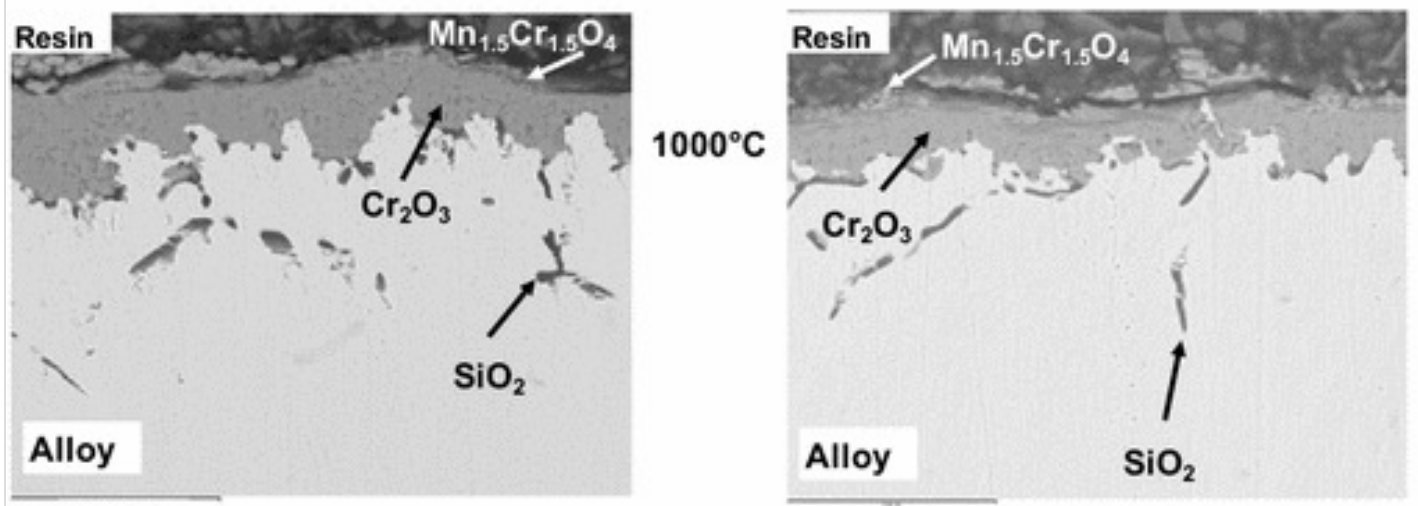

$20 \mu \mathrm{m}$

$20 \mu \mathrm{m}$
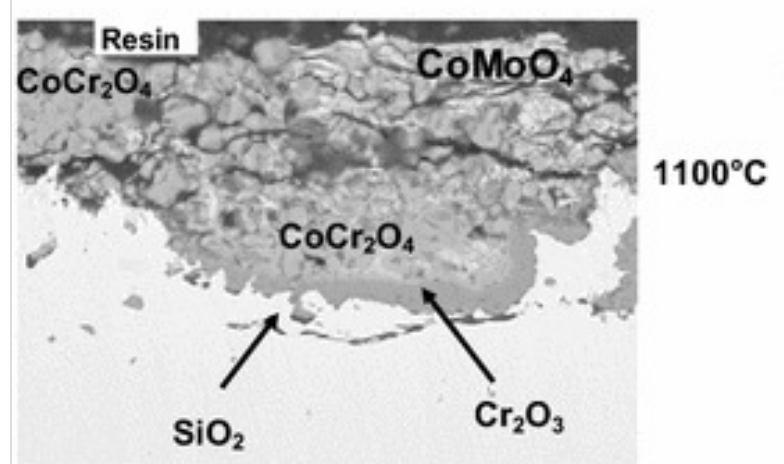

Alloy
$-20 \mu \mathrm{m}$

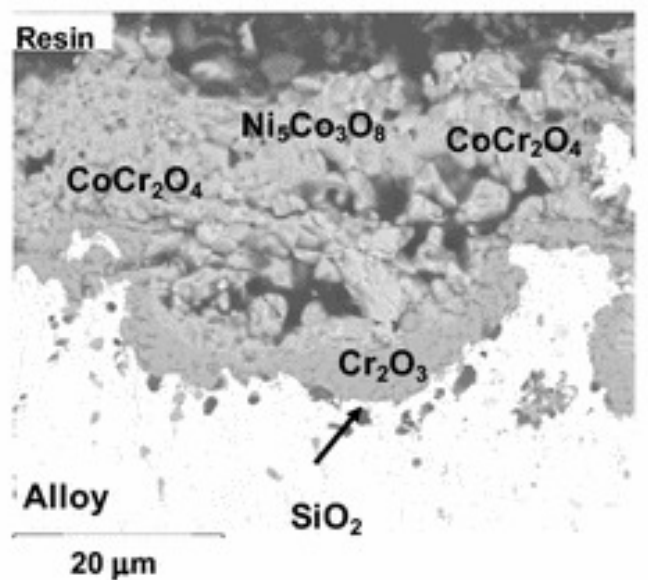

After 10 thermal cycles at $1,100{ }^{\circ} \mathrm{C}$ in dry air, the oxide scale cross-section shows a more complicated structure. Cobalt and molybdenum are present in 
the corrosion products. The porous outer scale is composed of $\mathrm{MoCoO}_{4}$ and $\mathrm{CoCr}_{2} \mathrm{O}_{4} \cdot \mathrm{Cr}_{2} \mathrm{O}_{3}$ is compact and located as a thin oxide scale at the internal interface. Silica is found at the alloy grain boundaries as internal corrosion products.

After 10 thermal cycles at $1,100{ }^{\circ} \mathrm{C}$ in wet air $\left(13\right.$ vol $\left.\% \mathrm{H}_{2} \mathrm{O}\right)$, the oxide scale cross-section shows a different structure. Cobalt and nickel are present in the corrosion products. The porous outer scale is composed of $\mathrm{Ni}_{5} \mathrm{Co}_{3} \mathrm{O}_{8}$ and $\mathrm{CoCr}_{2} \mathrm{O}_{4} \cdot \mathrm{Cr}_{2} \mathrm{O}_{3}$ is located as a porous oxide scale at the internal interface. Silica is found in the alloy close to the scale/alloy interface. The molybdenum-containing mixed oxide $\mathrm{CoMoO}_{4}$ is not observed in the oxide scale.

\section{Discussion}

\section{Kinetic Aspects}

The kinetic results obtained on the cobalt-based Phynox alloy between 800 at $1,100{ }^{\circ} \mathrm{C}$ are summarized in Table 2 . The parabolic behavior is always encountered in this temperature range. This permits the calculation of the parabolic rate constants $(\mathrm{kp})$ at each temperature. The Arrhenius plots of the $\mathrm{kp}$ values gives an apparent activation energy $\left(\mathrm{E}_{\mathrm{a}}\right)$ calculated from the slope of the curve shown on Fig. 12. Between 800 and $1,100{ }^{\circ} \mathrm{C}$ the apparent activation energy corresponds to $\mathrm{E}_{\mathrm{a}}=282 \pm 20 \mathrm{~kJ} \mathrm{~mol}^{-1}$ in dry air. In wet air $\left(13 \mathrm{vol} \% \mathrm{H}_{2} \mathrm{O}\right)$, the calculated apparent activation energy is $\mathrm{E}_{\mathrm{a}}=242 \pm 20 \mathrm{~kJ} \mathrm{~mol}^{-1}$ in the same temperature range. These values are close to those proposed in the literature for the oxidation of chromia-forming alloys considering diffusion-controlled mechanism of a chromia scale. According to other authors $\mathrm{E}_{\mathrm{a}}$ values are ranging between 250 to $290 \mathrm{~kJ}$ mol ${ }^{-1}$ for chromia scales [36-39]. The $\mathrm{E}_{\mathrm{a}}$ value and the XRD results and SEM-EDX analyses are in accordance with a scale growth mechanism limited by diffusion in a thickening $\mathrm{Cr}_{2} \mathrm{O}_{3}$ scale under isothermal conditions. The present results are different from those obtained by Zhang [12] because the alloying element content of the alloy T-800 is very different from the Phynox one.

\section{Fig. 12}

Arrhenius plot obtained from the parabolic rate constants relative to the Phynox specimens oxidation at $800,900,1,000$ and $1,100{ }^{\circ} \mathrm{C}$, in dry air, and 
in wet air $\left(13 \mathrm{vol} \% \mathrm{H}_{2} \mathrm{O}\right)$

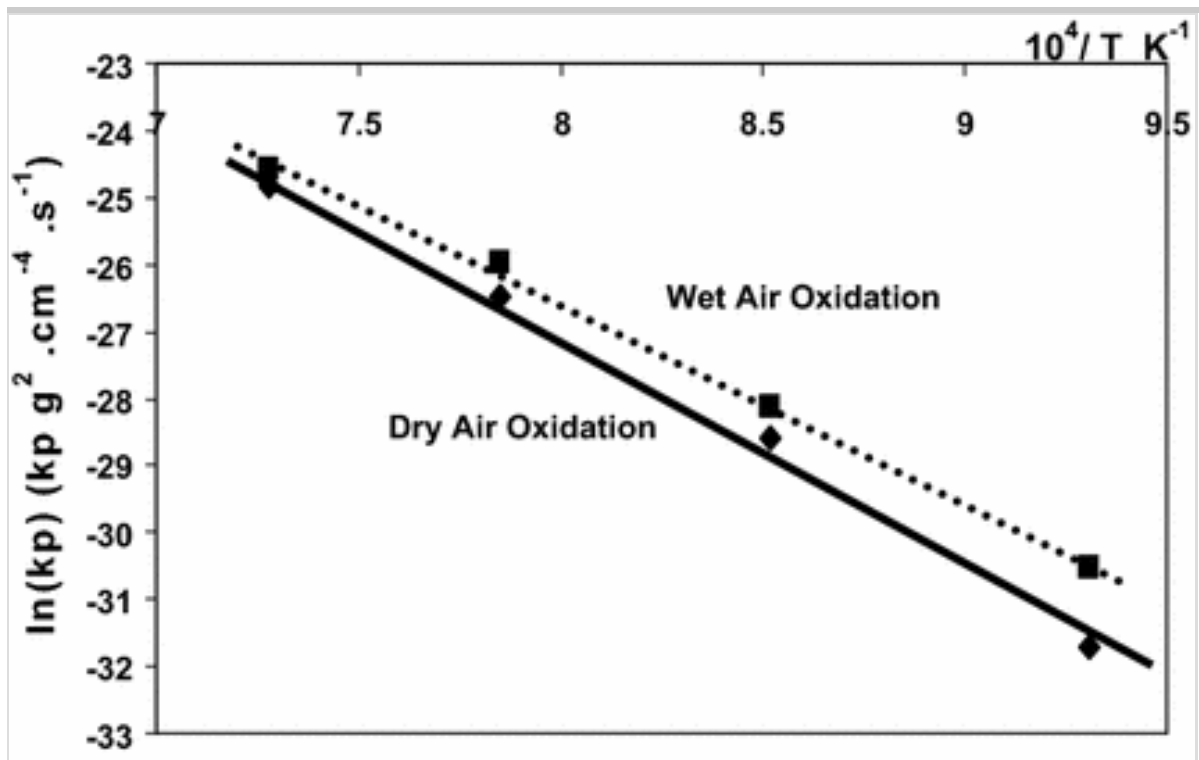

\section{Effect of Water Vapour on the Oxidation Rate}

The apparent activation energies are in good agreement with the SEM crosssection observation (Fig. 9) showing that the scale was mainly composed of a continuous chromia scale up to $1,100^{\circ} \mathrm{C}$, acting as a diffusion barrier. According to SEM (Figs. 8, 9) and XRD analyses (Figs. 4, 5), the parabolic kinetic behaviour between 800 and $1,100{ }^{\circ} \mathrm{C}$, in dry and moist air, appears to be mainly due to the absence of iron and cobalt in the scale and no breakaway oxidation at this stage. Figure 1 also show that water vapour increases the oxidation rate relative to those registered in dry conditions and the apparent activation energy is lower in wet air. Some authors proposed that the formation of the volatile hydroxide $\mathrm{CrO}_{2}(\mathrm{OH})_{2}$ could occur in wet air [28-30]. Vaporization is supposed to lead to chromium depletion in the alloy resulting in the formation of an iron-rich non-protective scale [33]. If vaporization occurs the oxidation rate is expected to be lowered in wet air. Figure 1 shows that the oxidation rate is higher during Phynox oxidation in wet air. In accordance with our results, Young explained that in short-term laboratory experiments when the weight gain is still important, chromium volatilization can usually be neglected, even in $\mathrm{O}_{2} / \mathrm{H}_{2} \mathrm{O}$ gas mixtures [31]. According to thermogravimetric results (Fig. 1), XRD (Figs. 4, 5) and SEM-EDX analyses (Figs. 8, 9), it should be noticed that the presence of manganese chromite at the scale/gas interface can hinder the volatilisation of $\mathrm{CrO}_{2}(\mathrm{OH})_{2}$ under wet conditions, as it was proposed by other authors [24, $40,41]$. We think that the higher oxidation rate is better due to a water vapour effect on chromia scale growth mechanism. Some authors have 
explained the inward transport of $\mathrm{H}_{2} \mathrm{O}$ into the oxide scale by the diffusion of hydrogen as $\mathrm{H}^{+}$and/or $\mathrm{H}_{2} \mathrm{O}$ in the oxide scale [18, 42, 43]. At high temperatures, in wet air, manganese chromite and chromia were observed during the first $24 \mathrm{~h}$ oxidation stage. It is proposed that water dissociation occurred on the specimen surface [23, 44, 45]. This dissociation is more important at high temperatures than at lower temperatures because water dissociation is endothermic. Then, the diffusion of hydrogen-containing species could occur. Transport of $\mathrm{H}_{2} \mathrm{O}$ into the oxide scales is performed by the incorporation of hydrogen in the form of $\mathrm{H}^{+}$or $\mathrm{H}_{2} \mathrm{O}[42,43,46]$. It is assumed that protons $\left(\mathrm{H}^{+}\right)$from water vapour might dissolve in the oxides and diffuse at grain boundaries. Essuman et al. proposed a model to explain the internal oxidation of chromium alloys [20, 21]. Ardigo et al. performed gold and deuterium marking experiments and have evidenced that $\mathrm{Fe}_{3} \mathrm{O}_{4}$ and $\mathrm{Cr}_{2} \mathrm{O}_{3}$ scales are permeable to hydrogen [47]. The low $\mathrm{H}^{+}$and $\mathrm{OH}^{-}$radii permit their diffusion through the oxide scale. Then, the increase of protons in the scale changes the oxide defect chemistry and could be responsible for the change in the growth mechanism. The effect of water vapour on transport mechanism within chromia scales is to increase cation vacancies and thus chromium diffusion is enhanced leading to vacancy condensation and pore formation as it is observed on the cross sections as dark gray spots in the chromia scale (Fig. 9). It can also be considered that the reaction of $\mathrm{H}^{+}$(and/or $\mathrm{H}_{2} \mathrm{O}$ ) with the metallic substrate under the chromia scale form $\mathrm{H}_{2}[33,48]$.

\section{Influence of Water Vapour on the Scale Adherence}

Figure 2 permits a comparison of the Phynox specimens oxidation rate after 10 cyles $(23+1 \mathrm{~h})$, in dry air and wet air $\left(13 \mathrm{vol} \% \mathrm{H}_{2} \mathrm{O}\right)$ at 800,900 and $1,000{ }^{\circ} \mathrm{C}$. After 5 cycles at $800{ }^{\circ} \mathrm{C}$, the mass gain registered is higher in wet air due to an increase of the alloy oxidation and a maintained good scale adherence. Results show that the scale is not duplex, but better composed of an oxide grain mixture (Figs. 10,11). Then, no external manganese chromite spalled off during thermal cycling conditions and the kinetic curves shows a higher mass gain compared to dry air cycling at $800{ }^{\circ} \mathrm{C}$ (Fig. 2). This is also due to the additional oxidation of cobalt. More oxide nodules are observed on the surface after wet air thermal cycling at $800^{\circ} \mathrm{C}$ (Fig. 10). This temperature is too low to induce a continuous chromia scale formation as proposed by some authors indicating that on $\mathrm{Co}-\mathrm{Cr}$ alloys the growth of $\mathrm{CoO}$ is faster than of $\mathrm{Cr}_{2} \mathrm{O}_{3}$ at low temperatures. When the temperature is 
raised, chromium diffusion becomes higher than cobalt diffusion [49]. This is confirmed at 900 and $1,000{ }^{\circ} \mathrm{C}$ where the temperature is high enough to maintain a continuous chromia scale on the Phynox surface after 10 cycles (Figs. 10,11 ). At 900 and $1,000^{\circ} \mathrm{C}$ the scale is only composed of a chromia scale and manganese chromite located at external interface (Figs. 5, 7). XRD patterns show that water vapour does not change the scale composition of scales obtained after cycling at 900 and $1,000{ }^{\circ} \mathrm{C}$. At $1,000{ }^{\circ} \mathrm{C}$, more scale spallation occured during wet air cycling and mainly concerns the external $\mathrm{Mn}_{1.5} \mathrm{Cr}_{1.5} \mathrm{O}_{4}$ spinel subscale, the internal chromia scale remains adherent on the surface and insure a good protection. Then, the net weight change registered corresponds to a weight loss (Fig. 2).

After 10 thermal cycles at $1,100{ }^{\circ} \mathrm{C}$ in dry air, the oxide scale cross-section shows that cobalt and molybdenum are present in the corrosion products (Fig. 7). The outer scale is composed of $\mathrm{MoCoO}_{4}$ located in the outer part of the scale and $\mathrm{CoCr}_{2} \mathrm{O}_{4}$ as the main constituent (Fig. 11). $\mathrm{Cr}_{2} \mathrm{O}_{3}$ is located as a thin oxide scale at the internal interface.

After 10 thermal cycles at $1,100{ }^{\circ} \mathrm{C}$ in wet air $\left(13\right.$ vol $\left.\% \mathrm{H}_{2} \mathrm{O}\right)$, the oxide scale cross-section shows a different structure (Fig. 11). Cobalt and nickel are present in the corrosion products. The porous outer scale is composed of $\mathrm{Ni}_{5} \mathrm{Co}_{3} \mathrm{O}_{8}$ and $\mathrm{CoCr}_{2} \mathrm{O}_{4}$ (Fig. 6). $\mathrm{Cr}_{2} \mathrm{O}_{3}$ is located as a porous oxide scale at the internal interface. EDX analyses in the alloy located close to the oxide/alloy interface show that the molybdenum content is close to $10 \mathrm{wt} \%$ (instead of $7 \mathrm{wt} \%$ in the bulk), indicating that no molybdenum depletion occurred in the metallic substrate and that no $\mathrm{MoO}_{2}(\mathrm{OH})_{2}$ volatilization is expected on this substrate in wet air.

The kinetic curves shown on Fig. 3 indicate that water vapour induces important weight losses compared to dry air conditions. Table 1 indicates that $14 \mathrm{wt} \%$ iron is present in the initial substrate. It is then important to look at the influence of this element on the water induced scale spallation at $1,100{ }^{\circ} \mathrm{C}$. EDX analyses performed in the oxide scale do not show any detectable amount of iron and EDX performed in the alloy indicate that the initial iron ratio is maintained between 17 and $14 \mathrm{wt} \%$. The highest iron relative ratio, close to the internal interface corresponds to the highest chromium depleted area. It then appears that on Phynox water vapour does not induce a breakaway oxidation due to the iron presence in the alloy as it is the case on numerous chromia forming alloys [50-52]. 
Figures 10 and 11, show that the bad scale adherence on the Phynox alloy at $1,100{ }^{\circ} \mathrm{C}$ is mainly due to the quick chromium alloy depletion leading to the cobalt oxidation and the non protective $\mathrm{CoCr}_{2} \mathrm{O}_{4}$ formation (Figs. 6, 7). This phenomenon is observed in dry and wet conditions but XRD results (Figs. 4, 5) obtained after $24 \mathrm{~h}$ isothermal oxidation indicate that water vapour induces more spinel spallation during cooling than observed after dry air oxidation. It is also observed on Fig. 9 that the chromia scale is porous after wet air oxidation at $1,100{ }^{\circ} \mathrm{C}$. EDX analyses performed in the alloy after 10 thermal cycles show that the chromium ratio is $7 \mathrm{wt} \%$ after wet air cycling and $14 \mathrm{wt} \%$ after dry air cycling $20 \mu \mathrm{m}$ deep inside the alloy. It indicates that the alloy chromium depletion is higher in wet air. This is either due to the higher weight loss $\left(30 \mathrm{mg} \mathrm{cm}^{-2}\right.$ instead of $7 \mathrm{mg} \mathrm{cm}^{-2}$ after 10 cycles) or to any $\mathrm{CrO}_{2}(\mathrm{OH})_{2}$ volatilization as proposed by other authors $[28-30]$.

Isothermal kinetic results obtained on Fig. 1 indicate that the oxidation rate is higher in wet conditions during the first $24 \mathrm{~h}$. This result is not in favour of a strong influence of $\mathrm{CrO}_{2}(\mathrm{OH})_{2}$ volatilisation. Nevertheless, in cycling conditions the manganese chromite spallation after the first cycle (Fig. 5) can favour this volatilisation during the wet thermal cycling test. The effect of water vapor on the increased scale decohesion at $1,100{ }^{\circ} \mathrm{C}$ is related to the porosities observed in the chromia scale on Fig. 9. Then this scale is no acting as a diffusion barrier and not only cobalt is oxidized to form $\mathrm{CoCr}_{2} \mathrm{O}_{4}$ but nickel is also oxidized to form $\mathrm{Ni}_{5} \mathrm{Co}_{3} \mathrm{O}_{8}$ due to the increased alloy chromium depletion (Fig. 6).

\section{Conclusions}

A cobalt based Phynox alloy has been oxidized in the $800-1,100{ }^{\circ} \mathrm{C}$ temperature range. Kinetic results show that the parabolic behaviour is followed under isothermal conditions in dry and wet air $\left(13 \mathrm{vol} \% \mathrm{H}_{2} \mathrm{O}\right)$. The scale growth mechanism of cobalt-base Phynox alloy in air is consistent with a growth mechanism limited by the diffusion process in a growing $\mathrm{Cr}_{2} \mathrm{O}_{3}$ scale. Water vapour is acting on the growth mechanism and enhances the alloy oxidation rate and chromia scale porosity. Thermal cycling tests at 900 and $1,000{ }^{\circ} \mathrm{C}$ show that water vapour reduces the outer spinel $\mathrm{Mn}_{1.5} \mathrm{Cr}_{1.5} \mathrm{O}_{4}$ subscale adherence. Then, the chromia scale adherence is not affected.

These temperatures permit a rapid chromium supply from the substrate to form a continuous chromia scale. Cycling at $800^{\circ} \mathrm{C}$ shows that water vapour 
leads to additional cobalt oxidation after 5 cycles. This temperature is to low to insure a sufficient chromium supply necessary to a protective chromia scale formation. At $1,100{ }^{\circ} \mathrm{C}$ thermal cycling conditions lead to the scale spallation and chromium depletion in the alloy. Then, important weight losses are registered corresponding to the oxidation of cobalt and molybdenum to induce the $\mathrm{CoCr}_{2} \mathrm{O}_{4}$ and $\mathrm{CoMoO}_{4}$ formation in dry air. In wet air, chromia is porous and permits nickel and cobalt oxidation leading to $\mathrm{Ni}_{5} \mathrm{Co}_{3} \mathrm{O}_{8}$ and $\mathrm{CoCr}_{2} \mathrm{O}_{4}$ formation and the highest weight losses.

\section{References}

1. P. Berthod, S. Michon, L. Aranda, S. Mathieu and J. C. Gachon, Computer Coupling of Phase Diagrams and Thermochemistry 27, 353 (2003).

2. P. Berthod, S. Michon, J. Di Martino, S. Mathieu, S. Noël, R. Podor and C. Rapin, Computer Coupling of Phase Diagrams and Thermochemistry 27, 279 (2003).

3. J. Di Martino, C. Rapin, P. Berthod, R. Podor and P. Steinmetz, Corrosion Science 46, 1865 (2004).

4. P. Berthod, P. Lemoine and L. Aranda, Materials Science Forum 595-598, 871 (2008).

5. H. Singh, Gitanjaly, S. Singh and S. Prakash, Applied Surface Science 255, 7062 (2009).

6. D. J. Baxter, D. Gilliland, F. Lanza, G. P. Toledo and F. Bregani, Materials Science Forum 251-254, 801 (1997).

7. C. Navas, M. Cadenas, J. M. Cuetos and J. de Damborenea, Wear 260, 838 (2006).

8. M. J. Tobar, J. M. Amado, C. Alvarez, A. Garcia, A. Varela and A. Yanez, Surface and Coating Technology 202, 2297 (2008).

9. T. Sahraoui, N. E. Fenineche, G. Montavon and C. Coddet, Journal of Materials Processing Technology 152, 43 (2004). 
10. T. Sahraoui, H. I. Feraoun, N. Fenineche, G. Montavon, H. Aourag and C. Coddet, Materials Letters 58, 2433 (2004).

11. A. Halstead and R. D. Rawlings, Journal of Materials Science 20, 1693 (1985).

12. Y.-D. Zhang, Z.-G. Yang, C. Zhang and H. Lan, Oxidation of Metals 70, 229 (2008).

13. P. J. Blau, T. M. Brummett, B. A. Pint and S. J. Shaffer, Wear 267, 380 (2009).

14. G. Michel, P. Berthod, M. Vilasi, S. Mathieu and P. Steinmetz, Surface and Coating Technology 205, 5241 (2011).

15. Y. Briol, Materials Science and Engineering A 528, 1117 (2011).

16. S. Fontana, S. Chevalier and G. Caboche, Journal of Power Sources 193, 136 (2009).

17. L. Antoni, Materials Science Forum 461-464, 1073 (2004).

18. A. Rahmel and J. Tobolski, Corrosion Science 5, 333 (1965).

19. H. Buscail, S. Heinze, P. Dufour and J. P. Larpin, Oxidation of Metals 47, 445 (1997).

20. E. Essuman, G. H. Meier, J. Zurek, M. Hänsel, L. Singheiser and W. J. Quadakkers, Scripta Materialia 57, 845 (2007).

21. E. Essuman, G. H. Meier, J. Zurek, M. Hänsel, T. Norby, L. Singheiser and W. J. Quadakkers, Corrosion Science 50, 1753 (2008).

22. D. L. Douglass, P. Kofstad, A. Rahmel and G. C. Wood, Oxidation of Metals 45, 529 (1996).

23. A. Galerie, S. Henry, Y. Wouters, M. Mermoux, J. P. Petit and L. Antoni, Materials at High Temperatures 22, 105 (2005). 
24. G. R. Holcomb and D. E. Alman, Scripta Materialia 54, 1821 (2006).

25. Y. Wouters, G. Bamba, A. Galerie, M. Mermoux and J. P. Petit, Materials Science Forum 461-464, 839 (2004).

26. H. Asteman, J. E. Svensson and L. G. Johansson, Oxidation of Metals 57, 193 (2002).

27. Shen Jianian, Zhou Longjiang and Li Tiefan, Oxidation of Metals 48, 347 (1997).

28. M. Schütze, D. Renusch and M. Schorr, Materials at High Temperatures 22, 113 (2005).

29. X. Peng, J. Yan, Y. Zhou and F. Wang, Acta Materialia 53, 5079 (2005).

30. E. J. Opila, Materials Science Forum 461-464, 765 (2004).

31. D. J. Young, Materials Science Forum 595-598, 1189 (2008).

32. Y. P. Jacob, V. A. C. Haanappel, M. F. Stroosnijder, H. Buscail, P. Fielitz and G. Borchardt, Corrosion Science 44, 2027 (2002).

33. N. K. Othman, N. Othman, J. Zhang and D. J. Young, Corrosion. Science 51, 3039 (2009).

34. R. Rolland, C. Issartel, S. Perrier and H. Buscail, Corrosion Engineering. Science and Technology 46, 634 (2011).

35. H. Buscail, F. Riffard, C. Issartel and S. Perrier, Corrosion Engineering. Science and Technology 47, 404 (2012).

36. W. C. Hagel and A. U. Seybolt, Journal of the Electrochemical Society 108, 1146 (1961).

37. J. H. Chen, P. M. Rogers and J. A. Little, Oxidation of Metals 47, 381 (1997). 
38. H. Buscail, S. El Messki, F. Riffard, S. Perrier, R. Cueff, E. Caudron and C. Issartel, Materials Chemistry and Physics 111, 491 (2008).

39. H. Buscail, S. El Messki, F. Riffard, S. Perrier, R. Cueff and C. Issartel, Journal of Materials Science 43, 6960 (2008).

40. V. P. Deodeshmukh, Oxidation of Metals 79, 567 (2013).

41. D. Schmidt, M. Galetz and M. Schütze, Oxidation of Metals 79, 589 (2013).

42. A. Galerie, Y. Wouters and M. Caillet, Materials Science Forum 369-370, 231 (2001).

43. T. Norby, Advances in Ceramics 23, 107 (1987).

44. Cheng Shen-Yuan, Kuan Sheng-Lih and Tsai Wen-Ta, Corrosion Science 48, 634 (2006).

45. C. Issartel, H. Buscail, Y. Wang, R. Rolland, M. Vilasi and L. Aranda, Oxidation of Metals 76, 127 (2011).

46. T. Norby, Journal de Physique IV 3, 99 (1993).

47. M. R. Ardigo, I. Popa, S. Chevalier, S. Weber, O. Heintz and M. Vilasi, Oxidation of Metals 79, 495 (2013).

48. N. K. Othman, J. Zhang and D. J. Young, Corrosion Science 52, 2827 (2010).

49. P. Kofstad, High temperature corrosion (Chap. 10), (Elsevier Applied Science Publishers Ltd., London, 1988), p. 373.

50. C. S. Tedmon, Journal of the Electrochemical Society 113, 766 (1966).

51. G. Ben Abderrazik, G. Moulin and A.M. Huntz, Oxidation of Metals 33, 191 (1990). 
52. H. M. Tawancy, Oxidation of Metals 45, 323 (1996). 